\title{
Clostridium Perfringens Toxins Involved in Mammalian Veterinary Diseases
}

\author{
F. A. Uzal*,1, J. E. Vidal, ${ }^{2}$ B. A. McClane ${ }^{2,3}$ and A. A.Gurjar ${ }^{2}$
}

${ }^{1}$ California Animal Health and Food Safety Laboratory System, San Bernardino Branch, School of Veterinary Medicine, University of California, Davis, San Bernardino, CA 92408, USA, ${ }^{2}$ Department of Microbiology and Molecular Genetics and ${ }^{3}$ Molecular Virology and Microbiology Graduate Program, University of Pittsburgh School of Medicine, Pittsburgh, PA 15261, USA

\begin{abstract}
Clostridium perfringens is a gram-positive anaerobic rod that is classified into 5 toxinotypes (A, B, C, D, and E) according to the production of 4 major toxins, namely alpha (CPA), beta (CPB), epsilon (ETX) and iota (ITX). However, this microorganism can produce up to 16 toxins in various combinations, including lethal toxins such as perfringolysin $\mathrm{O}$ (PFO), enterotoxin (CPE), and beta2 toxin (CPB2). Most diseases caused by this microorganism are mediated by one or more of these toxins. The role of CPA in intestinal disease of mammals is controversial and poorly documented, but there is no doubt that this toxin is essential in the production of gas gangrene of humans and several animal species. $\mathrm{CPB}$ produced by $C$. perfringens types $\mathrm{B}$ and $\mathrm{C}$ is responsible for necrotizing enteritis and enterotoxemia mainly in neonatal individuals of several animal species. ETX produced by $C$. perfringens type D is responsible for clinical signs and lesions of enterotoxemia, a predominantly neurological disease of sheep and goats. The role of ITX in disease of animals is poorly understood, although it is usually assumed that the pathogenesis of intestinal diseases produced by $C$. perfringens type $\mathrm{E}$ is mediated by this toxin. $\mathrm{CPB} 2$, a necrotizing and lethal toxin that can be produced by all types of $C$. perfringens, has been blamed for disease in many animal species, but little information is currently available to sustain or rule out this claim. CPE is an important virulence factor for $C$. perfringens type A gastrointestinal disease in humans and dogs; however, the data implicating CPE in other animal diseases remains ambiguous. PFO does not seem to play a direct role as the main virulence factor for animal diseases, but it may have a synergistic role with CPA-mediated gangrene and ETX-mediated enterotoxemia. The recent improvement of animal models for $C$. perfringens infection and the use of toxin gene knock-out mutants have demonstrated the specific pathogenic role of several toxins of $C$. perfringens in animal disease. These research tools are helping us to establish the role of each $C$. perfringens toxin in animal disease, to investigate the in vivo mechanism of action of these toxins, and to develop more effective vaccines against diseases produced by these microorganisms.
\end{abstract}

Keywords: Alpha, beta, Clostridium perfringens, CPB2, CPE, epsilon, iota, toxins.

\section{INTRODUCTION}

Clostridium perfringens is a gram-positive anaerobic rod that is classified into 5 toxinotypes (A, B, C, D, and E) according to the production of 4 major toxins, namely alpha (CPA), beta (CPB), epsilon (ETX) and iota (ITX) (Table 1). However, this microorganism can produce up to 16 toxins in various combinations, including lethal toxins such as perfringolysin $\mathrm{O}(\mathrm{PFO})$, enterotoxin (CPE), and beta2 toxin (CPB2) [1-4].

C. perfringens causes numerous gastrointestinal infections in most mammalian species (Table 2). These infections are generically called enterotoxemias because toxins produced in the intestine may be absorbed into the general circulation. However, while this is true for many $C$. perfringens toxins, some toxins produced in the intestine act only locally. This microorganism can also cause diseases of skin, subcutaneous and muscular tissues (gas gangrene or

*Address correspondence to this author at the California Animal Health and Food Safety Laboratory System, San Bernardino Branch, School of Veterinary Medicine, University of California, Davis, San Bernardino, CA 92408, USA; E-mail: fuzal@cahfs.ucdavis.edu malignant edema). Most, if not all diseases produced by $\mathrm{C}$. perfringens are mediated by one or more of its powerful toxins. We review here the most studied $C$. perfringens toxins involved in mammalian veterinary diseases.

\section{ALPHA TOXIN (CPA OR PLC)}

\section{Structure and Mechanism of Action}

Alpha-toxin (CPA or PLC) is produced by all $C$. perfringens strains (Table 1), although toxinotype A strains usually produce higher amounts than the other toxinotypes [5]. The main properties of this toxin are summarized in Table 3. CPA is a $43 \mathrm{kDa}$ protein comprised of 370 amino acids. It contains two domains, an alpha-helical $\mathrm{N}$-terminal domain harboring the phospholipase $\mathrm{C}$ active site, and an alpha-sandwich C-terminal domain which is involved in membrane binding. CPA has more than 50\% identity at the amino acid level, and/or on the basis of antigenic crossreactivity, to the phospholipases $\mathrm{C}$ from Clostridium bifermentans, Clostridium novyi, Clostridium baratii and Clostridium absonum [3]. CPA is a classic example of a toxin that modifies cell membranes by enzymatic activity. This toxin is a zinc-dependent phospholipase $\mathrm{C}$ which degrades phosphatidylcholine and sphingomyelin, both components of the eukaryiotic cell membranes [6], causing 
Table 1. Major Toxins Produced by the Five Toxinotypes of Clostridium perfringens

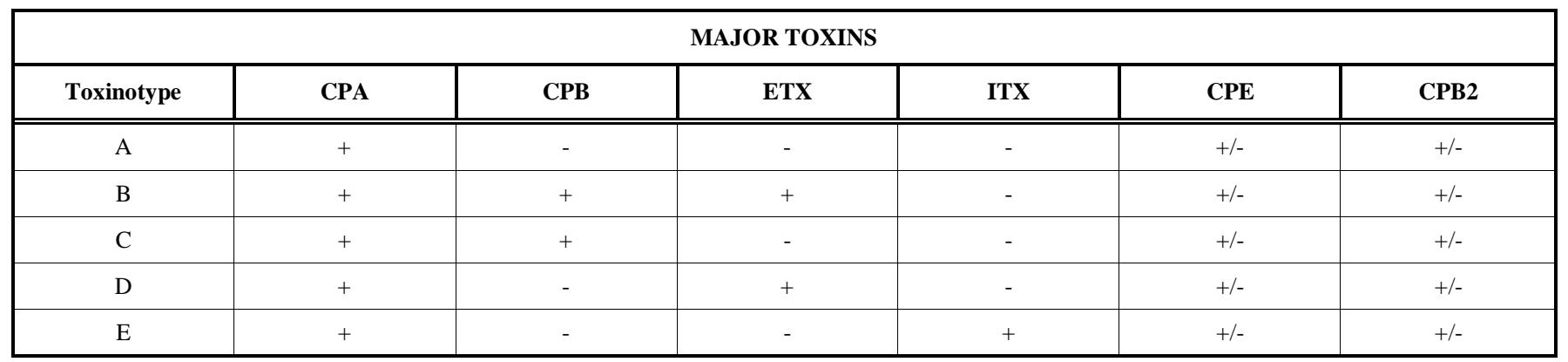

Table 2. Main Diseases Associated to C. perfringens Major Toxins in Domestic Mammals

\begin{tabular}{|c|c|c|c|c|c|c|}
\hline & Sheep & Goat & Cattle & Pigs & Horses & Other species \\
\hline \hline CPA & Yellow lamb disease & Not confirmed & Not confirmed & Not confirmed & Not confirmed & Not confirmed \\
\hline CPB & $\begin{array}{c}\text { Lamb dysentery } \\
\text { Struck }\end{array}$ & $\begin{array}{c}\text { Necrotizing } \\
\text { enteritis }\end{array}$ & Necrotizing enteritis & $\begin{array}{c}\text { Necrotizing } \\
\text { enteritis (mainly } \\
\text { piglets) }\end{array}$ & $\begin{array}{c}\text { Necrotizing } \\
\text { enteritis (mainly } \\
\text { foals) }\end{array}$ & $\begin{array}{c}\text { Necrotizing enteritis } \\
\text { in several species }\end{array}$ \\
\hline ETX & Enterotoxemia & Enterotoxemia & Possible Enterotoxemia & Not reported & Not reported & Not reported \\
\hline ITX & Enteritis & Not reported & Enterritis & Not reported & Not reported & Enterotoxemia in \\
rabbits
\end{tabular}

damage on the membrane of erythrocytes and other cells from many animal species. The net result of this action is cell lysis, by degradation of membrane phospholipids [7]. CPA also activates several other membrane and internal cell mechanisms that lead to hemolysis [6-8]. In addition, CPA activates the arachidonic cascade resulting in the formation of thromboxanes, leukotrienes and prostaglandins, which activate the inflammation cascade and produce vasoconstriction $[6,9]$.

In combination with $\mathrm{PFO}, \mathrm{CPA}$ allows $C$. perfringens to escape macrophage phagosomes and survive in the host tissue [10]. CPA in sublytic amounts impairs the migration of leukocytes and promotes their aggregation by several different mechanisms including hyperadhesion with leucostasis at the periphery of lesions [11]. These free intravascular aggregates are responsible for the blockade of blood flow in small vessels, and subsequently for the anoxia and necrosis of tissues [12-15] which in turn helps create anaerobic conditions for the proliferation of $C$. perfringens.

\section{Genetics of CPA}

All $C$. perfringens strains possess the gene encoding CPA. This gene (cpa) is chromosomally encoded and located close to the origin of replication, which is one of the most stable regions within the bacterial chromosome [16]. This chromosomal location of the cpa gene contrasts with many of the other major toxin genes of $C$. perfringens, which are plasmid borne [16-19]. Nucleotide sequencing of the cpa gene from type A strain ACTC 13124, a high CPA producer, revealed a single open reading frame that includes a putative prokaryotic signal sequence [20]. The cpa genes from other type $\mathrm{A}$ and types $\mathrm{B}-\mathrm{E}$ strains of $C$. perfringens have been characterized, showing that they are also located chromosomally [16].

A two component regulatory system named VirS/VirR positively regulates the in vitro transcription of cpa via a RNA regulatory molecule called VR-RNA [21-24]. Transcription of cpa and production of the CPA protein is also regulated by the recently described $C$. perfringens Agr quorum sensing system $[25,26]$. Whether those systems act in concert to regulate cpa transcription still needs to be clarified.

\section{Role of CPA in Animal Diseases}

\section{Intestinal Infections}

The role of CPA in intestinal disease of mammals is controversial and poorly documented (Table 2). In sheep, $C$. perfringens type A causes yellow lamb disease [27], a rare form of acute enterotoxemia in lambs. Information about pathogenesis of this disease is minimal and often contradictory, but it is generally assumed that most clinical signs and lesions are due to the effects of CPA [27]. However, no definitive proof of the action of this toxin in the pathogenesis of yellow lamb disease has been provided. The disease is characterized clinically by depression, anemia, icterus, and hemoglobinuria. Necropsy findings include pale and friable liver and spleen and the presence of red urine in 
Table 3. Main Properties of the Major Toxins of C. perfringens (Modified from Sakurai, 1995)

\begin{tabular}{|c|c|c|c|c|c|c|c|}
\hline & CPA & CPB & ETX & ITX & PFO & CPE & CPB2 \\
\hline Molecular weight & $42.528 \mathrm{kDa}$ & $35 \mathrm{kDa}$ & $34 \mathrm{kDa}$ & $\begin{array}{l}\text { Ia: } 47,500 \\
\text { Ib: } 71,500\end{array}$ & $54 \mathrm{kDa}$ & $35 \mathrm{kDa}$ & $28 \mathrm{kDa}$ \\
\hline $\begin{array}{l}\text { LD 50* } \\
\text { (mice) }\end{array}$ & $3 \mu \mathrm{g}$ & $\begin{array}{c}1.87 \mu \mathrm{g} / \mathrm{ip} ; 30 \mathrm{ng}- \\
50 \mu \mathrm{g} / \mathrm{iv}\end{array}$ & $100 \mu \mathrm{g}$ & $\begin{array}{l}\text { Ia: } 620 \mu \mathrm{g} \\
\text { Ib: } 940 \mu \mathrm{g}\end{array}$ & $\begin{array}{l}\text { Not } \\
\text { reported }\end{array}$ & $50 \mu \mathrm{g}$ & $0.3 \mu \mathrm{g}$ \\
\hline Biological activity & $\begin{array}{l}\text { Lethal } \\
\text { Necrotizing } \\
\text { Hemolytic } \\
\text { Contraction of } \\
\text { smooth } \\
\text { muscle }\end{array}$ & $\begin{array}{c}\text { Dermonecrotic } \\
\text { Edema, } \\
\text { Enterotoxic, } \\
\text { Cytotoxic }\end{array}$ & $\begin{array}{l}\text { Dermonecrotic } \\
\text { Lethal } \\
\text { Edema } \\
\text { Contraction of } \\
\text { smooth muscle }\end{array}$ & $\begin{array}{c}\text { Lethal } \\
\text { Necrotizing }\end{array}$ & $\begin{array}{l}\text { Lethal, } \\
\text { Necrotizi } \\
\text { ng }\end{array}$ & $\begin{array}{c}\text { Erythema } \\
\text { Lethal } \\
\text { Enterotoxic }\end{array}$ & $\begin{array}{l}\text { Dermonecrotic } \\
\text { Edema, } \\
\text { Enterotoxic, } \\
\text { Cytotoxic }\end{array}$ \\
\hline Thermostability & Stable & $\begin{array}{c}\text { Inactivated at } \\
60^{\circ} \mathrm{C} \text { (Sakurai } \\
\text { and Duncan, } \\
1978 \text { ), } \\
\sim 2 \text { month at - } \\
80^{\circ} \mathrm{C}\end{array}$ & $\begin{array}{l}\text { Up to } 1 \text { week at } \\
\text { room temperature, } \\
\text { several months at - } \\
20 \mathrm{C} \\
\text { years at }-80 \mathrm{C}\end{array}$ & $\begin{array}{l}\text { Ia. Stable } \\
\text { Ib: Labile }\end{array}$ & Unknown & $\begin{array}{l}\text { Inactivated at } \\
\quad 60^{\circ} \mathrm{C} \\
<1 \text { week at RT } \\
\sim 1 \text { month at - } \\
20^{\circ} \mathrm{C} \text {, years } \\
\text { lyophilized }\end{array}$ & Unknown \\
\hline Reaction to Trypsin & Susceptible & $\begin{array}{c}\text { Sensitive } \\
\text { (inactivated) }\end{array}$ & Activated (resistant) & $\begin{array}{l}\text { Activated } \\
\text { (resistant) }\end{array}$ & $\begin{array}{l}\text { Susceptib } \\
\text { le }\end{array}$ & $\begin{array}{l}\text { Activated } \\
\text { (resistant) }\end{array}$ & $\begin{array}{l}\text { Sensitive } \\
\text { (inactivated) }\end{array}$ \\
\hline
\end{tabular}

*: per kg of mouse

ip: intraperitoneal injection

iv: intravenous injection

the urinary bladder [27]. Histopathological changes include periacinar necrosis of the liver, splenic congestion, nephrosis with hemoglobin casts, and pulmonary congestion and edema [27].

C. perfringens type A has been and is still frequently blamed for enteritis, abomasitis and/or enterotoxemia in cattle [28-32], horses [33-39], goats [40-43] and pigs [44, 45]. However, the role of this microorganism in natural diseases of these species remains controversial and poorly documented [46]. Although it has been suggested that clinical signs and pathological findings in several of these diseases may be the result of CPA action, no definitive evidence has become available that proves the role of CPA in the pathogenesis. While large amounts of CPA are detected in feces of naturally infected cattle [45] (and some of the species mentioned above), CPA is also present in the intestinal content of many clinically healthy animals by which detection of CPA in intestinal content of sick animals does not have diagnostic relevance for type A disease.

Results of experimental work with $C$. perfringens type A or purified CPA suggest that this microorganism, and probably CPA, can produce disease in several mammalian species [30, 31, 43, 47]. However no definitive proof of this causal relationship has been provided and the role of this microorganism and its major toxin (CPA) in intestinal disease remains controversial. Intraruminal inoculation of $C$. perfringens type A into healthy calves induced anorexia, depression, bloat, diarrhea, and sometimes death [30, 31]. However, enteric disease could not be reproduced by the inoculation of large amounts of $C$. perfringens type $\mathrm{A}$ in the small intestine of cattle [46].

Neonatal pigs experimentally inoculated with $C$. perfringens type A developed enteropathy and intragastric administration of CPA to piglets caused disease with symptoms similar to those seen in naturally acquired disease thought to be caused by $C$. perfringens type A [43].

Ligated ovine ileal and colonic loops incubated with $C$. perfringens type A CPA retained more fluid than control loops due to inhibition of water absorption and developed a mild to moderate multifocal infiltration of neutrophils in the lamina propria and submucosa. These results suggested that CPA could be responsible for diseases of intestinal origin in sheep [48].

The intravascular hemolysis and capillary damage, platelet aggregation, hepatic necrosis and cardiac effects seen in several animal species, with presumptive type A infection, are consistent with the action of a circulating toxin such as CPA. Studies with toxin gene mutants have been performed to study the role of CPA in chickens [49]. However, to our knowledge, very few studies have been performed involving gastrointestinal tract challenge exposure of mammals with isogenic $C$. perfringens type A mutants that do or do not produce CPA. For instance, vegetative cultures of cpe null mutants of type A that still produce CPA, did not produce damage to the intestinal mucosa in rabbit ileal loops [50]. Cultures of $c p b$ null mutants of type $\mathrm{C}$ isolates still producing CPA, did not produce fluid accumulation in rabbit ileal loops [51]. Studies with isogenic $C$. perfringens toxin mutants in large animals will be necessary to definitely establish the role of CPA in pathogenesis of intestinal disease in these species.

\section{Gangrene/Malignant Edema}

Studies with isogenic mutants strongly suggest that CPA is the major $C$. perfringens toxin involved in gas gangrene in humans [52], which is characterized by extensive local tissue 
destruction and necrosis progressing to shock and death [53, 54].

C. perfringens type $\mathrm{A}$ is also involved in gas gangrene (malignant edema) of domestic mammals including sheep, cattle, goats, and horses, acting alone or in combination with other clostridial species [55]. Although the condition is most frequently described affecting subcutaneous tissue and muscle, gangrenous mastitis produced by $C$. perfringens type A has also been reported in cattle and sheep [56, authors unpublished observation]. Predisposing factors for this disease in animals include trauma associated to injections, shearing, castration, docking and milking. Although CPA has long been considered the main virulence factor for malignant edema of animals and vaccines containing alpha toxoid seem to protect against this disease, no final evidence of the role of CPA in the pathogenesis of malignant edema has been provided. Also, the fact that most cases of malignant edema in food-producing animals are associated with a mixed clostridial infection (which may or may not include $C$. perfringens type A) suggests that, even if CPA is responsible for some cases of malignant edema, other clostridial toxins can also produce this disease.

Grossly, malignant edema is characterized by severe subcutaneous and muscular edema, skeletal muscle necrosis and generalized petechiae on serous membranes, the latter being a manifestation of terminal disseminated intravascular coagulation due to toxemia. Histologically, in contrast to other bacterial myonecrosis, $C$. perfringens gas gangrene and malignant edema are characterized by a marked absence of inflammatory cells in affected tissues and the accumulation of leukocytes within vessels at the lesion periphery, most likely due to the inhibitory effect that CPA has over leukocyte migration.

Experimentally, CPA is lethal for mice, dermonecrotic and hemolytic. When injected intravenously, CPA suppresses the myocardial contractility and induces hypotension, bradychardia, shock and multiorgan failure. The myotoxic effects could result from a direct activity of CPA on muscle cell membrane, from alteration of local blood flow, and/or inflammatory mediators as a consequence of endothelial cells stimulated by CPA [54]. The role of CPA in gas gangrene was demonstrated by protection of mice against this disease by immunization with recombinant CPA, and by reduced virulence of CPA knock-out mutants of $C$. perfringens when injected into mice [52].

\section{CLOSTRIDIUM PERFRINGENS BETA TOXIN (CPB)}

\section{Structure and Mechanism of Action}

The main properties of this toxin are summarized in Table 2. The $c p b$ gene encodes a prototoxin of 336 amino acids that includes a 27-amino acid signal sequence removed during secretion, resulting in a mature toxin of $\sim 35 \mathrm{kDa}[57$, 58]. Purified CPB is thermolabile, with $>90 \%$ of its lethal activity being inactivated by incubation for $1 \mathrm{~h}$ at $50^{\circ} \mathrm{C}$ (or $10 \mathrm{~min}$ at $100^{\circ} \mathrm{C}$ ). $\mathrm{CPB}$ is also highly sensitive to in vitro trypsin $[58,59]$ and pepsin [60] treatment. Low $\mathrm{pH}$ does not seem to affect its activity [60].

The deduced CPB amino acid sequence shares similarity with several pore-forming toxins, including $28 \%$ similarity to Staphylococcus aureus alpha-toxin and 22,28 or $18 \%$ similarity with the A, B, C components of gamma-toxin, respectively [57]. While those toxins cause hemolysis in erythrocytes from several species $[61,62], \mathrm{CPB}$ is nonhemolytic for rabbit or sheep erythrocytes [63].

It is interesting that while $S$. aureus alpha-toxin, and many other pore forming toxins [64], are cytotoxic for a wide variety of cells [including leukocytes, rabbit kidney cells, smooth muscle cells and fibroblasts [61], CPB-induced cytotoxicity has thus far only been reported for HL-60 cells, HUVEC (human umbilical vein endothelial cell) and intestinal I407 cells [61,65-68].

\section{Genetics of $\mathbf{c p b}$}

CPB is encoded by the $c p b$ gene, which is carried on virulence plasmids [58, 69] of different molecular size (authors unpublished observations). The $c p b$ gene has been cloned and sequenced from type $\mathrm{B}$ and $\mathrm{C}$ isolates, which revealed a very similar ORF of $\sim 1000$ bp [57, 70]. A possible Shine-Dalgarno region is located $7 \mathrm{bp}$ upstream of the first ATG start codon.

Despite the proven importance of $\mathrm{CPB}$ in type $\mathrm{C}$ (and probably type $\mathrm{B}$ ) disease (see discussion later), relatively little is known about regulation of the $c p b$ gene in vitro or in vivo. However, recent studies demonstrated that in the presence of human enterocyte-like Caco-2 cells, CPB production is rapidly upregulated. The VirS/VirR two component regulatory system (TCRS) was shown to be involved in modulating this early production of the CPB protein by upregulating $c p b$ transcription [71].

The VirS/VirR system also controls transcription of other C. perfringens toxins (i.e. $p f o \mathrm{~A}, p l c / c p a, c p b 2$ ) by either direct binding of the VirR response regulator to VirR boxes located upstream of the target gene, or indirectly through RNA regulatory molecules [23, 24, 72-74]. However, VirR boxes are not detectable within $\sim 800 \mathrm{bp}$ upstream of the $c p b$ gene, raising the possibility that a regulatory RNA molecule might control $c p b$ transcription via the VirS/VirR system [74].

Quorum sensing mechanisms provide a molecular signal(s) that activates TCRS $[75,76]$. C. perfringens encodes at least two different quorum sensing systems, i.e. the Lux and the Agr systems [25, 26, 77]. A type C luxS mutant still normally regulated its $c p b$ transcription and CPB production, both in vitro and in vivo [26]. Recent studies have found that the $C$. perfringens agr locus regulates pfo $\mathrm{A}$ and cpa/plc transcription and PFO and CPA/PLC production, in strain 13 $[25,26]$. Additional studies are currently underway to determine the involvement of this novel system in regulating CPB production.

\section{Role of CPB in Animal Diseases}

$\mathrm{CPB}$ is responsible for diseases in several animal species (Table 2) and it is produced by types $\mathrm{B}$ and $\mathrm{C}$ of $C$. perfringens. Type $\mathrm{B}$ isolates cause an often fatal hemorrhagic dysentery in sheep, and possibly in other species, while type $\mathrm{C}$ isolates cause enteritis necroticans (also called pigbel) in humans and necrotic enteritis and/or enterotoxemias in almost all livestock species. Both types B and $\mathrm{C}$ animal disease are often accompanied by sudden death or acute neurological signs $[2,4,78,79]$. 
Type B disease is a rare occurrence in farm animals and mostly seen in Middle East countries and the UK. Clinical disease can be characterized by diarrhea, neurological signs or both. Post-mortem gross and histopathological findings are similar to those of type $\mathrm{C}$ infections (see below), except for those rare cases of focal symmetrical encephalomalacia, believed to be due to the effect of ETX [79, 80].

Clinical signs and histopathologic findings in type $\mathrm{C}$ infections are very similar in most livestock animal species. The course of disease can be peracute, acute, or chronic, with signs of the acute and peracute condition including intense abdominal pain, depression, and bloody diarrhea. Chronic disease can occur in older animals of some species (e.g. pigs), and it is characterized by persistent diarrhea without blood and dehydration [43].

At necropsy, the predominant lesions are most frequently observed in small intestine, but cecum and spiral colon can sometimes be involved; occasionally, lesions may be confined to large intestine. Lesions are similar in all segments of intestine, and in acute cases consist of intestinal and mesenteric hyperemia, diffuse or segmental, extensive fibrinonecrotic enteritis, with emphysema and bloody gut contents. Mesenteric lymph nodes are red, an excess of hemorrhagic peritoneal and pleural fluid is found, there may be fibrin strands on intestinal serosa, and adhesions may develop between intestinal loops.

Histologically, the hallmark of acute disease is hemorrhagic necrosis of the intestinal wall which starts in the mucosa but usually progresses to affect all layers of the intestine. Lesions are morphologically similar in all segments of intestine. The luminal surface is covered by a pseudomembrane composed of degenerated and necrotic desquamated epithelial cells, cell debris, inflammatory cells, fibrin, and a variable number of large, thick bacilli with square ends with occasional subterminal spore [81]. The superficial epithelium and layers of lamina propria are necrotic. Fibrin thrombi occluding superficial arteries and veins of the lamina propria are characteristic of this condition. Diffuse edema with variable amounts of protein and inflammatory cell exudate can be seen throughout all intestinal layers, including serosa [81].

There is currently limited information regarding the pathogenic mechanism of type B-associated diseases, but some evidence indicates that both CPB and ETX (another potent toxin produce by type $\mathrm{B}$ isolates) may contribute to lethality [82]. The mechanism of pathogenesis of type C disease is under active investigation. We experimentally demonstrated that CPB is necessary and sufficient to cause type $\mathrm{C}$ pathology in a rabbit ileal loop model [51]. Type C disease has also been linked to endogenous trypsin deficiency or the presence, in the intestines, of trypsin inhibitors due to diet. CPB is very trypsin sensitive, so low trypsin levels or the presence of trypsin inhibitors likely contribute to disease by favoring CPB persistency in the gastrointestinal tract $[2,51,83,84]$. Type $\mathrm{B}$ and C animal disease is more frequently seen in neonatal animals than at any other age $[4,5,79]$. This age predilection is associated to the inhibitory effect that the colostrum has over intestinal trypsin. This inhibitory effect is an innate mechanism of defense, during the first hours of life, which protect the immunoglobulins present in the colostrum against protease activity of trypsin.

C. perfringens types $\mathrm{B}$ and $\mathrm{C}$ disease begins in the host intestine $[2,4,79]$ with absorption of toxin(s) from the intestines into the circulation that then leads to the death of an infected animal. Different animal models have been developed to help in understanding the mechanism of those diseases involving CPB intoxication [51, 83, 85, 86]. Early work demonstrated that $C$. perfringens type $C$ could cause a pigbel-like disease in guinea pigs fed a persistent low protein diet, combined with dietary protease inhibitors [83]. In that study it was hypothesized that the low protein diet was a predisposing factor in both humans and guinea pigs, because of low intestinal protease production in malnourished individuals. Enteric lesions similar to those observed in human pigbel cases or animals with type $\mathrm{C}$ enteritis were also successfully reproduced by injecting a type $\mathrm{C}$ culture, along with a protease inhibitor, into lambs [84].

The role of CPB in type C-induced intestinal disease has recently been experimentally demonstrated by inoculating into rabbit ileal loops a series of $C$. perfringens type $\mathrm{C}$ toxin mutants, along with trypsin inhibitor [51]. Experimental type C pathology induced by wild type isolate CN3685 was characterized by accumulation of abundant hemorrhagic fluid (Fig. 1), complete loss of absorptive cells along the villi, and coagulation necrosis of the lamina propria. Confirming the role of $\mathrm{CPB}$, two different $c p b$ mutants were unable to cause fluid accumulation or intestinal damage, while complementing back $\mathrm{CPB}$ expression to the mutant completely restored virulence (Fig. 1) [51].

For many years, efforts to reproduce intestinal type $\mathrm{C}$ disease by injecting purified CPB into animals had been unsuccessful [4]. However, our recent work reproduced type $\mathrm{C}$ pathology by injecting native $\mathrm{CPB}$, along with trypsin inhibitor, into rabbit intestinal loops [51, 87]. The CPBinduced intestinal lesions, produced in this model, were similar to those described in type C natural disease [4, 51, $79,87]$. This work was also significant because it established that purified $\mathrm{CPB}$ is a very potent toxin in the rabbit small intestine (i.e. one microgram was sufficient to cause severe intestinal damage within $1 \mathrm{~h}$ ) [87].

As mentioned earlier, the lethality of type $\mathrm{C}$ infection has long been attributed to absortion of toxin(s) from the intestine to the circulation. Several studies have proven that purified CPB is highly lethal for mice [58, 59, 63, 85]. A study by Fisher et al. [85] later demonstrated, using the mouse intravenous injection lethality model, that CPB is the main lethal factor present in type C late-log-phase culture supernatants. In the study referred to [85], type $\mathrm{C}$ isolates growing in vitro maximally produced beta toxin during late$\log$ phase. Lethality induced by type C culture supernatants, or purified CPB, could be blocked by preincubation with a monoclonal anti-CPB antibody, but not with a monoclonal anti-CPA antibody (i.e. CPA is also produced by nearly all type $\mathrm{C}$ strains) [85].

To study lethality in a more adequate context of infection, we developed two mouse models for type C infection 60]. In those models, mice were inoculated intragastrically or directly in the duodenum with type $\mathrm{C}$ isolates, type $\mathrm{C}$ toxin mutants or purified $\mathrm{CPB}$, along with 


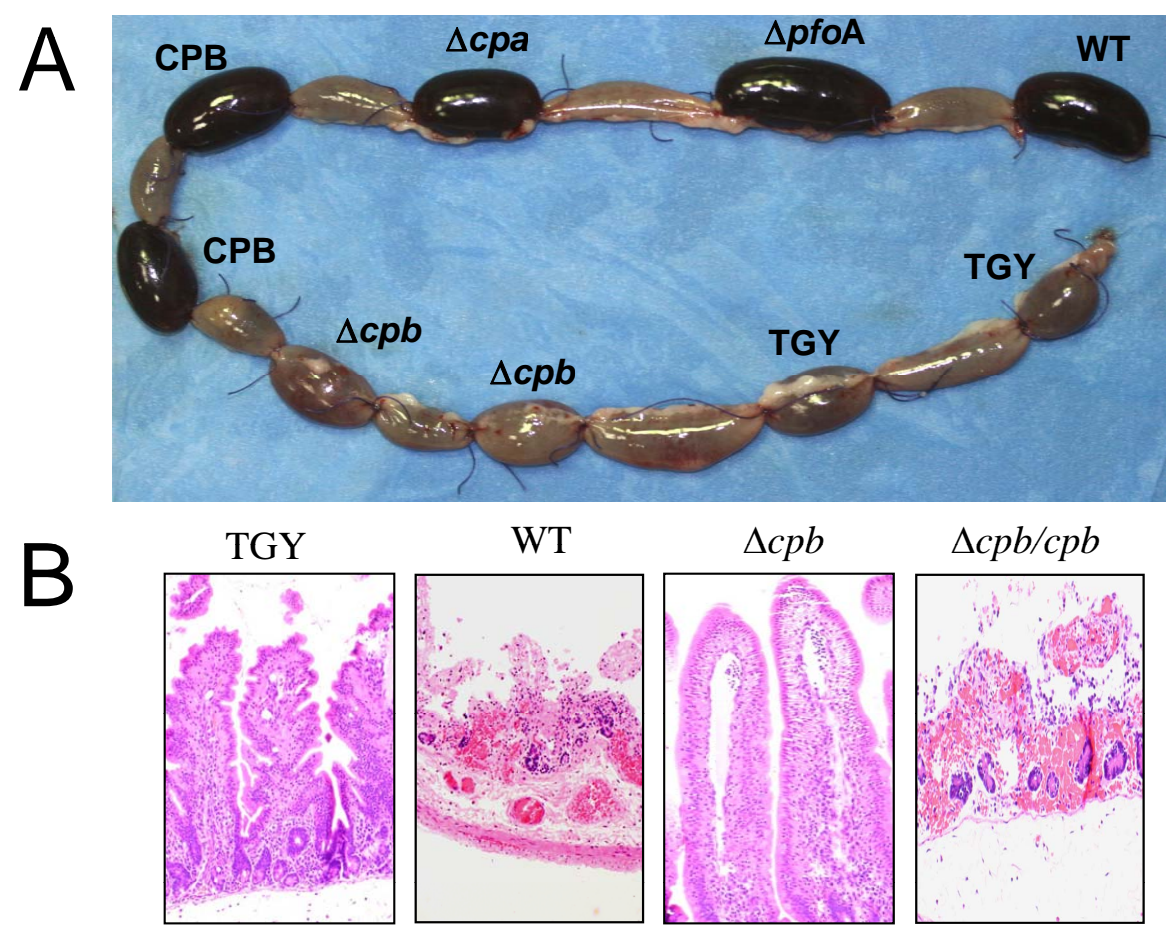

Fig. (1). CPB-mediated gross pathology and histological damage of rabbit ileal intestinal loops. Rabbit ligated intestinal loops were inoculated with a type C CN3685 isolate (WT), isogenic single toxin mutants, purified CPB or medium (unioculated TGY medium) and then incubated for 6 h. A) Gross pathology. Loops inoculated with the WT, $\Delta p f o$ A, $\Delta c p a$, or purified CPB are severely hemorrhagic and distended with fluid. No significant gross abnormalities are observed in the loops inoculated with two different $\Delta c p b$ mutants or sterile TGY medium. B) Histology. Control loops inoculated with sterile TGY, and loops inoculated with the $\Delta c p b$ mutant showed normal intestinal villi with a well-preserved epithelium and lamina propria. Loops inoculated with wild type CN3685 (WT) or the complemented $\Delta c p b / c p b s$ howed histological damage consisting of necrosis and loss of epithelium, necrosis of lamina propria, blunting of the villi, hemorrhage of the mucosa and diffuse neutrophilic infiltration of mucosa and sub mucosa (Reproduced from Sayeed et al. 2008, with permission from Wiley Blackwell publisher).

trypsin inhibitor. Type $\mathrm{C}$ strains or purified $\mathrm{CPB}$ reproduced neurological signs and mouse lethality. Prior to the death of challenged mice, animals experienced sudden spastic muscle contraction, tetany and opisthonous, supporting that the toxin(s) acts on the autonomic nervous system. Two different type $\mathrm{C}$ null $c p b$ mutants produced no lethality in mice, clearly indicating that $\mathrm{CPB}$ is the main contributor to type C lethality [60].

A mutational analysis study [63] found that the arginine residue at position 212 of $\mathrm{CPB}$ is important for mouse lethality. Tyrosine 191, its counterpart in $S$. aureus alphatoxin, a metabolite that has $28 \%$ homology with $\mathrm{CPB}$, is located in the putative binding domain [57]. Whether CPB must bind a specific organ, or cell type, is still unknown. Some evidence has suggested that CPB may target the nervous system [59, 88, 89].

Another study determined that the CPB cysteine residue (at position 265) is not absolutely required for lethal activity. However, this work showed that adding functional groups at cysteine 265 (which induces steric hindrance) or changing residues 266, 268, and 275 caused a complete loss of lethal activity [90]. The authors proposed that the C-terminal region of $\mathrm{CPB}$ is either required for beta toxin binding to receptor, if any, or for formation of beta toxin oligomers.

The molecular basis of CPB-induced damage during type $\mathrm{B}$ or type $\mathrm{C}$ disease is under investigation. Previous reports found that purified $\mathrm{CPB}$ forms pores in the membranes of leukocyte-derived HL-60 cells or human umbilical vein endothelial cells $[66,68]$. Studies with recombinant toxin also demonstrated that CPB forms pores in bilayer lipid membranes. Those channels induce $\mathrm{K}^{+}$efflux and $\mathrm{Ca}^{2+}, \mathrm{Na}^{+}$ and $\mathrm{Cl}^{-}$influxes, which then produce cell swelling and lysis. The mutation of arginine 212 in CPB to aspartate, previously shown to increase the $50 \%$ lethal dose of CPB for mice by nearly 13-fold [63], significantly reduced the ability of CPB to form channels. The size of the $\mathrm{CPB}$ pore has been calculated as approximately $12 \AA$ [59].

Purified CPB produces abundant dermonecrosis, edema and plasma extravasation when directly injected into the skin of guinea pigs or mice [91, 92]. CPB also provokes the release of TNF- $\alpha$ and IL-1 $\beta$, as well as activates tachykinin $\mathrm{NK}_{1}$ receptors by a still unknown mechanism $[86,91]$.

Gibert et al. (1997) [65] first reported that CPB induces cell rounding and detachment of intestinal I407 cells [65]. In vivo, type $\mathrm{B}$ and type $\mathrm{C}$ isolates produce intestinal lesions consisting of diffuse or multifocal hemorrhagic and necrotizing enteritis, mainly in the ileum, with excess of sanguineous serous fluid in the abdominal cavity [79]. Similar intestinal lesions have been observed after inoculating purified CPB into rabbit intestinal loops [51, 87].

In recent work, Miclard et al. showed that $\mathrm{CPB}$ specifically binds vascular endothelial cells, during peracute 
or acute cases of type $\mathrm{C}$-induced disease in piglets or humans. The authors reported that binding of CPB to those cells produced acute endothelial degeneration and vascular necrosis [93, 94].

It is evident that CPB plays an important role in $C$. perfringens type $\mathrm{C}$, and maybe in type $\mathrm{B}$, disease. Those diseases are often lethal with a fatal outcome within $48 \mathrm{~h}$. The first target of CPB during type $\mathrm{C}$ infection is the host intestine, where the toxin is highly active. This damage to the intestinal epithelium might allow $\mathrm{CPB}$ and other toxins to be translocated into the circulation to induce its lethal effects.

\section{EPSILON TOXIN (ETX)}

\section{Structure and Mechanism of Action}

The main properties of epsilon toxin (ETX) are summarized in Table 3. ETX is an example of an aerolysinlike, pore-forming toxin. $C$. perfringens ETX and $C$. septicum alpha-toxin are structurally related to aerolysin although ETX shows no significant sequence homology with aerolysin at the amino acid level. ETX and $C$. septicum alpha-toxin form heptameric pores, like aerolysin, and are very potent cytolysins [3].

ETX is considered the major virulence factor of $C$. perfringens types B and D [19]. This toxin causes blood pressure elevation, increased contractility of smooth muscle, vascular permeability increase, as well as brain and lung edema in multiple animal species, while in goats ETX also causes colitis [79, 95]. ETX is the third most potent clostridial toxin after botulinum toxin and tetanus toxin, with a mouse lethal dose of $100 \mathrm{ng} / \mathrm{kg}$ [3]. ETX is secreted as a prototoxin $(32,981 \mathrm{Da})$ [96], which is converted into a fully active toxin $(\sim 1000$ times more toxic than the prototoxin) when activated by proteases such as trypsin, chymotrypsin, and a metalloproteinase named lambda toxin that is produced by $C$. perfringens $[42,97,98]$.

ETX is also active on a few cell lines, including Madin Darby Canine Kidney (MDCK) and to a lesser extent human leiomyoblastoma (G-402) [99, 100]. This toxin also kills guinea-pig and rabbit peritoneal macrophages in vitro, but had no demonstrable effect on other cells from guinea pigs, rabbits, mice, sheep or goats [101, 102]. When ovine, caprine and bovine aortic endothelial cells were challenged with ETX in vitro, no morphological alterations were observed in these cells even when large doses of toxin were used for several hours [102]. In the study referred to [102]

it was speculated that the absence of damage to aortic endothelial cells was due to the need for ETX to act in concert with elements present in the living animal but not in vitro and/or differences between endothelial cells of the brain and those in the aorta [102].

In MDCK cells, marked swelling is observed in the first phase of intoxication, followed by blebbing and membrane disruption [103]. ETX binds to the MDCK cell surface, preferentially to the apical site, and recognizes a putative specific membrane receptor which is not present in insensitive cells. Binding of the toxin to its receptor leads to formation of large membrane complexes (about $155 \mathrm{kDa}$ ) which are very stable when the incubation is performed at $37^{\circ} \mathrm{C}$ [103]. In contrast, the complexes formed at $4{ }^{\circ} \mathrm{C}$ are dissociated by SDS and heating [103]. The cytotoxicity in MDCK cells is associated with pore formation that causes a rapid loss of intracellular $\mathrm{K}^{+}$, an increase of $\mathrm{Cl}^{-}$and $\mathrm{Na}^{+}$, with an increase of $\mathrm{Ca}^{++}$occuring later. In polarized MDCK cells, ETX induces a rapid and dramatic increase in permeability and it is thought that pore formation in the cell membrane is likely responsible for the permeability change of cell monolayers. Actin cytoskeleton and organization of tight and adherens junctions are not altered, and the paracellular permeability to macromolecules is not significantly increased upon ETX treatment [104, 105]. Toxin-dependent cell signaling leading to cell necrosis is not yet fully understood, but it includes ATP depletion, AMPactivated protein kinase stimulation, mitochondrial membrane permeabilization, and mitochondrial-nuclear translocation of apoptosis-inducing factor, which is a potent caspaseindependent cell death factor [104].

In the brain, microvascular endothelial damage by this toxin appears to be the fundamental cause of cerebral parenchymal injury and lesions occur in an apparently doseand time-dependant manner. Large doses of circulating toxin produce a severe, generalized vasogenic cerebral edema and an acute or peracute clinical course to death. With lower doses in partially immune animals, bilaterally symmetrical focal necrosis, occurs in certain selectively vulnerable brain regions [106]. The precise pathogenesis of the brain damage is unresolved, but the following sequence of events was proposed by Buxton and Morgan (1976): ETX reacts with specific receptor sites in the brain endothelium, causing vascular endothelial cells to degenerate. This alters fluid dynamics, which in turn causes the astrocyte end-feet to swell and rupture. Serum proteins and eventually red blood cells leak out and the resultant brain edema and haemorrhage produce parenchymal necrosis, which is responsible for the clinical nervous signs and the histopathological changes seen during acute intoxication of sheep and occasionally in goats.

In addition, degenerative and necrotic changes have been described in brain neurons of rats subacutely intoxicated with ETX even before vascular changes in the brain were evident [107]. Finnie et al. (1999) [107] suggested that after gaining access to the brain tissue by producing an increase in vascular permeability, ETX later exerts a direct cytotoxic effect on neurons. It was demonstrated that ETX passes through the blood-brain barrier and accumulates specifically in the brain [106, 108-110]. ETX toxin binds with high affinity to rat brain synaptosomes [111], and limited evidence suggests that the receptor might be a sialoglycoprotein $[109,111,112]$. The neurological disorders observed in several animal species seem to result from ETX action on hippocampus, leading to an excessive release of glutamate [108, 113, 114].

In summary, ETX would act on the brain by affecting vascular permeability but also by direct action on neurons. The precise target cell in host and mechanism of ETX action on neuronal cells remain to be elucidated.

\section{Genetics of etx}

The ETX gene (etx) is localized on conjugative plasmids $[51,115]$, with most type B isolates possessing the same $\sim 65$ $\mathrm{kb}$ etx plasmid that also carries the gene encoding beta2 toxin [115]. The etx gene in type B, and some type D, 
isolates is flanked by IS1151 and a gene related to the transposase (tnpa) gene from $\mathrm{Tn} 3$ transposons that lie upstream of etx. A region with similarity to transposases from S. aureus and Lactococcus is located downstream from etx [115-117].

\section{Role of ETX in Animal Diseases}

ETX-producing $C$. perfringens type D strains are the most common cause of clostridial enterotoxemia in sheep and goats (Table 2). Since the gross and histological changes observed in type D enterotoxemia have been reproduced by intravenous inoculation of ETX in sheep and goats [118], there is little doubt that the pathogenesis $C$. perfringens type $\mathrm{D}$ enterotoxemia is largely mediated by ETX.

C. perfringens type $\mathrm{D}$ produces an acute, subacute, or chronic neurological condition in sheep, characterized by sudden death or neurological and respiratory signs, including blindness, opisthotonos, convulsions, bleating, frothing from the mouth, and recumbency with paddling immediately before death. Diarrhea is occasionally observed, although this is not a common clinical sign in sheep [79, 119].

When present, intestinal gross changes consist of hyperemic small intestine mucosa with slight to marked red fluid contents. Colitis may occur, but is not a consistent finding in sheep enterotoxemia. Several gross findings, such as excess pericardial, pleural, and/or abdominal fluids (with or without fibrin strands), which may clot on exposure to air, serosal petechiation, and lung edema are frequently seen [79]. Gross changes in sheep are rarely observed in brain, and consist of herniation of the cerebellar vermis (cerebellar coning) in acute or subacute cases and focal symmetrical encephalomalcia (FSE), in chronic cases. FSE is characterized by dark hemorrhagic foci in corpus striatum, thalamus, midbrain, and cerebellar peduncles and white matter [120-122]. The kidney lesion from which one of the common names of the disease is derived (pulpy kidney disease) is likely to be a postmortem change [80, 123].

Microscopic changes in the brain of sheep with type D infection are unique and pathognomonic, and they are present in approximately $90 \%$ of cases [120, 124]. They consist of perivascular proteinaceous edema (microangiopathy) in the brain [120] (Fig. 2). In the rarely observed chronic form of the disease, necrosis of white matter, grossly known as FSE, can be observed [122]. This lesion is usually multifocal and characterized by degeneration of white matter, hemorrhage, and astrocyte and axonal swelling. Perivascular edema and degeneration, and necrosis of brain parenchyma, are always bilateral and symmetrical, and they have been described most frequently in corpus striatum, thalamus, midbrain, cerebellar peduncles, and cerebellar white matter $[120,121]$. These areas are not exclusively affected, and lesions can sometimes be seen in other parts of brain, such as cortex and hippocampus [120]. Usually, no significant histological changes are found in the intestine of sheep dying from enterotoxemia [124, 125]. Histological changes were not observed in kidneys of experimentally inoculated lambs necropsied immediately after death [124], supporting suggestions that these lesions are due to postmortem change.

In goats, type D produces acute, subacute, or chronic disease as well. The acute form occurs more frequently in young, unvaccinated animals and is clinically similar to the acute disease in sheep [126, 127]. The subacute form is more frequently seen in adult goats [128], vaccinated or not, and is characterized by hemorrhagic diarrhea, abdominal discomfort, severe shock, opisthotonos, and convulsions. The disease may result in death 2-4 days after onset [41, 127], but some animals recover. Adult animals, often vaccinated, can also exhibit chronic disease [128], which is characterized by profuse, watery diarrhea (often containing blood and mucus), abdominal discomfort, weakness, anorexia, and agalactia [126]. This chronic form may last for days or weeks [129].

Gross changes in acute caprine type D enterotoxemia are similar to those in the ovine disease. In the chronic form of the disease in goats, fibrinohemorrhagic colitis with occasional involvement of the distal small intestine seems to be the most consistent lesion [126]. A combination of the findings in acute and chronic forms of disease are frequently seen in subacute forms. The so-called pulpy kidney has not been reported in caprine enterotoxemia, nor has cerebellar herniation or FSE.

In goats, there are few descriptions of histological changes in type D enterotoxemia, and changes in brain are not considered a consistent feature of caprine enterotoxemia. Nevertheless, perivascular edema and degeneration of white matter, similar to those observed in sheep, can be observed in cases of acute and subacute caprine enterotoxemia [130].

In addition, subacute and chronic type D enterotoxemia
in goats are characterized by fibrinonecrotic
(pseudomembranous) colitis with large numbers of
intralesional Gram-positive bacilli [128]. Microscopic
lesions in kidney are not characteristic of goat
enterotoxemia.

In cattle there are few reports about natural cases of type D enterotoxemia, and information about clinical and pathologic findings of the disease in this species is scant and frequently contradictory [131-133]. A condition called enterotoxemia of cattle, allegedly produced by $C$. perfringens type $\mathrm{D}$, is described in textbooks [55,134]

but confirmation of the etiology of this condition remains unestablished. The occurrence of FSE, similar to the lesion observed in type D enterotoxemia of sheep, has been described by several authors in cattle [134-139] but to date no causal relationship between these lesions and $C$. perfringens type $\mathrm{D}$ has been established. Recently, natural type D enterotoxemia was described in two young calves, in which the disease was confirmed by the presence of perivascular proteinaceous edema in the brain and detection of ETX in intestinal contents [140]. These seem to be the first confirmed cases of type D enterotoxemia in cattle.

The effects of intravenous ETX have been studied in sheep [118, 120], goats [118], cattle [46, 141], mice [85, $142,143]$ and rats [107]. The toxin produces increased vascular permeability in many tissues, the most significant effects of which are acute pulmonary and cerebral edema with albumin extravasation. This has been demonstrated by immunohistochemistry, which shows strong perivascular immunoreactivity around blood vessels showing perivascular edema. Also, in rats given ETX intravenously, widespread upregulation of aquaporine 4 (a member of the membrane 
A

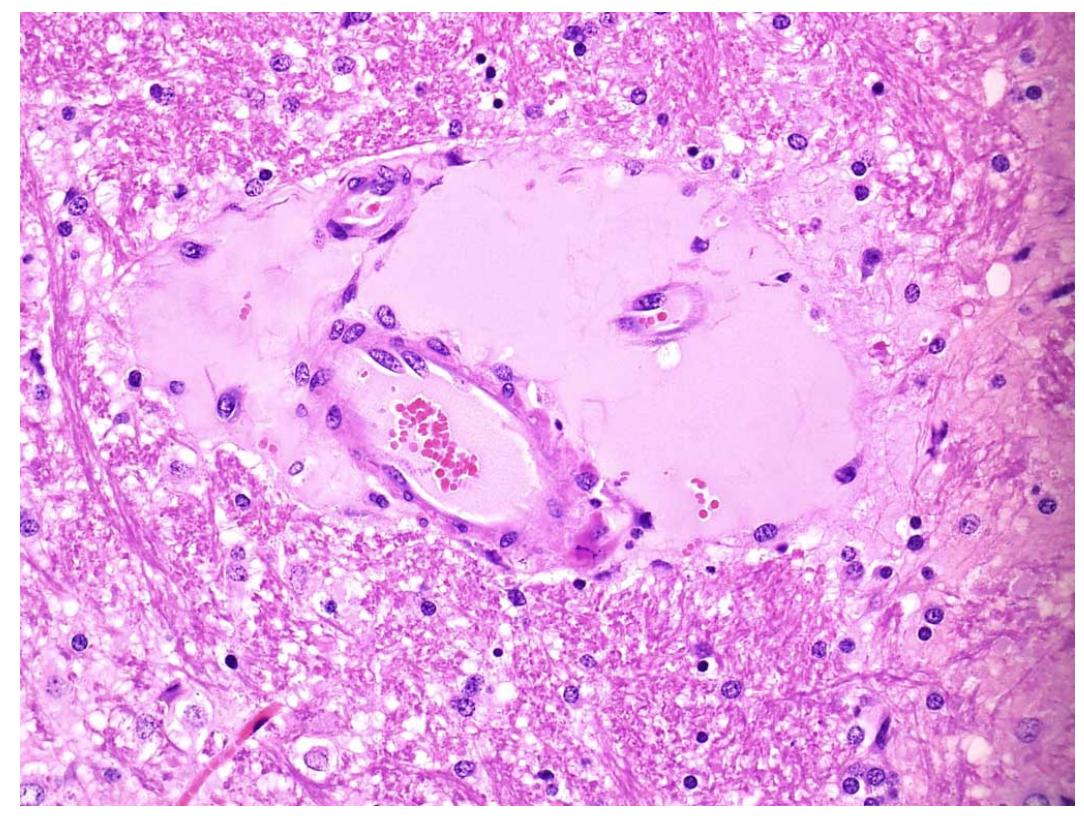

B

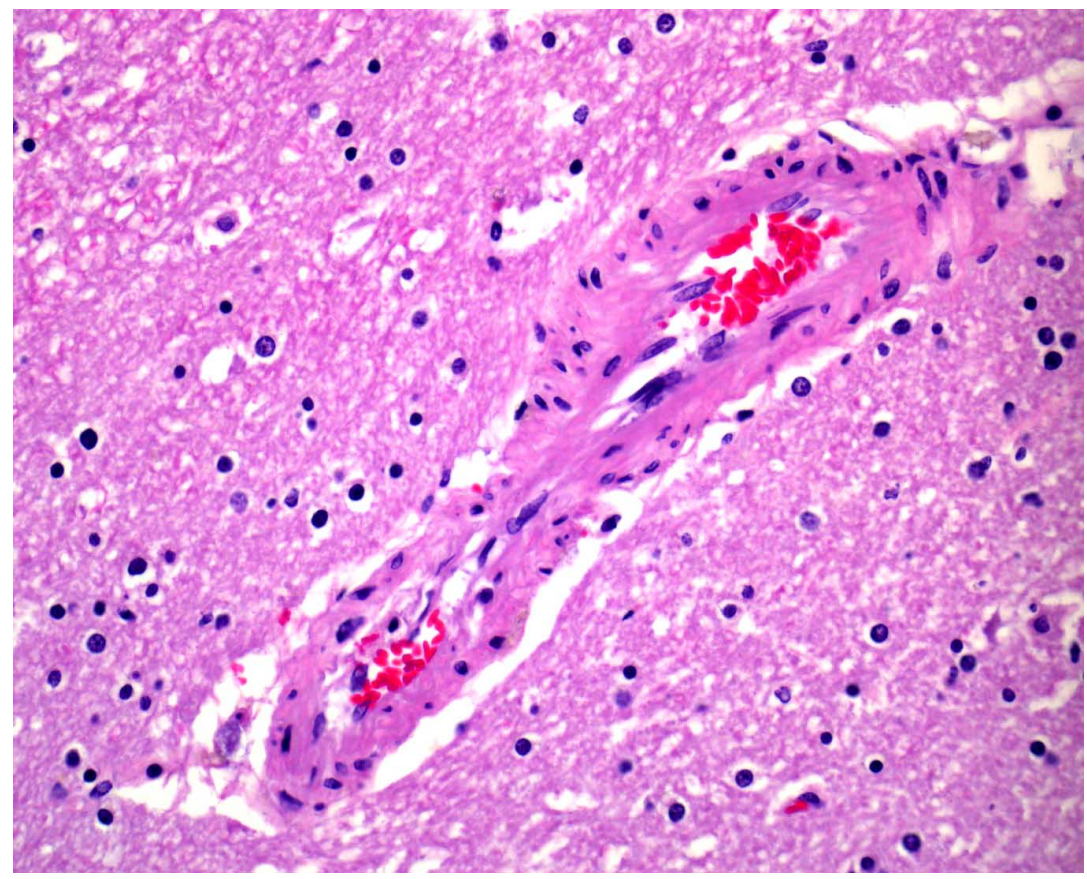

Fig. (2). A) Proteinaceous perivascular edema in the brain of a lamb with type D enterotoxemia. The edema of the brain in this disease is mediated by the action of ETX. HE, 250x. (Reproduced from Uzal F.A., Ortega Porcel J. and Corpa Arenas J.M., 2008. Enterotoxemia ovina y caprina. Cuadernos de Campo, Merial Ed., Barcelona, Spain). B) Brain from a normal lamb is shown for comparison. HE, 250x.

water-channel proteins, which is important in the regulation of water balance in the brain and facilitates reabsorption of excess fluid) was observed in astrocytes [144]. These results suggest that aquaporin 4 has a role in the clearance of edema fluid from brains damaged by ETX. The administration of formalinized epsilon prototoxin to mice prevented leakage of horse radish peroxidase from the brain vasculature of mice given ETX via the same route $[145,146]$. Based on these results, it was suggested that ETX exerts its effects through specific receptor sites on the vascular endothelium and that antigenically similar formalinized epsilon prototoxin blocks this effect [145].
In mice given intravenous ETX the granular layer of the cerebellum seems to be the area most frequently affected and lesions progress from an initial vasogenic edema to malacic foci with bilateral symmetry, and with a predilection for the white matter [142]. Ultrastructurally the initial findings include swelling of astrocytes, especially their perivascular extensions and astrocytes in the cerebellum appeared to be particularly sensitive to ETX. These changes are quickly followed by severe endothelial damage with the endothelial cytoplasm becoming attenuated, vacuolated and very electron-dense [143]. Studies with immunohistochemistry demonstrated that after ETX administration to rats, there is 
rapid opening of the blood-brain barrier to albumin [147]. Renal tubular lesions were described in mice inoculated experimentally with ETX, but not in ruminants.

Niilo et al. [46] induced disease by intraduodenal inoculation of whole cultures of $C$. perfringens type $\mathrm{D}$ and dextrin in eight calves. Two of the animals presented acute neurological signs and severe pulmonary edema, hydrothorax, hydroperitoneum and serosal hemorrhages, while the other six did not show clinical or pathological changes. However, no histologic lesions were described in any of the animals [146]. Uzal et al. [141] reported acute loss of consciousness, hyperaesthesia, intermittent tonic and clonic convulsions, recumbency and dyspnea in calves inoculated intravenously with $C$. perfringens type D ETX. These calves showed severe acute pulmonary edema and varying degrees of perivascular proteinaceous edema in the internal capsule, thalamus and cerebellum. While the gross and histologic findings described in the calves inoculated with ETX were very similar to changes in acute enterotoxemia of sheep, the experimental procedures involved intravenous injection of ETX and this cannot, therefore, be considered a model of natural disease. Recently, a disease clinically and pathologically identical to ovine enterotoxemia was reproduced in cattle by intraduodenal inoculation of whole cultures of $C$. perfringens type D [148], which seems to fulfill Koch's postulates for type $\mathrm{D}$ disease in cattle.

\section{IOTA TOXIN}

\section{Structure and Mechanism of Action}

The main properties of iota toxin (ITX) are summarized in Table 3. C. perfringens ITX is a clostridial binary toxin. These toxins have a common structure consisting of two independent protein components that are not covalently linked, one being the binding component ( $\mathrm{Ib}, 100 \mathrm{kDa})$, and the other the enzymatic component (Ia, $45 \mathrm{kDa}$ ) [149]. Both components are required for biological activity. The crystal structure of Ia has been solved, which revealed some resemblance to the ADP-ribosylating B. cereus vegetative insecticidal protein [150].

The ITX family components are synthesized during exponential growth phase and secreted by means a signal peptide as inactive proteins. They are proteolytically activated by trypsin or chymotrypsin, removing a $20 \mathrm{kDa} \mathrm{N}$ terminal peptide from the binding component $(80 \mathrm{kDa}$ for the active form) and 9 to $11 \mathrm{~N}$-terminal residues from the enzymatic component [151]. Ib triggers the internalization of Ia into the cell by receptor-mediated endocytosis $[152,153]$. The mature binding component recognizes a specific cell membrane receptor [154] and then heptamerizes to form ion permeable channels, allowing the enzymatic component to escape from endocytic vesicles into the cytosol upon an acidic pulse $[65,133,149,155,156]$. Once activated by trypsin, Ib forms heptamers that insert into the membrane and form pores permitting the passage of molecules such as ions. Ib remains on the cell surface up to $3 \mathrm{~h}$ and mediates the endocytosis of Ia molecules [157].

The most prominent effects of ITX include depolymerization of actin filaments and increase of G-actin monomers. This effect results from Ia-mediated ADP- ribosylation of G-actin at Arg-177 [150]. The intermediate filaments are also disorganized, whereas the microtubules are not affected. The final result of this is change in morphology (rounding), inhibition of migration and activation of leucocytes [158], inhibition of smooth muscle contraction, impairment of endocytosis, exocytosis, and cytokinesis. Depolymerization of the actin cytoskeleton by ITX induces disorganization of tight and basolateral intercellular junctions with a subsequent increase in permeability of cultured intestinal cell monolayers [157].

\section{Genetics of itx}

The components of ITX are encoded by two genes, iap $(\sim 1160 \mathrm{nt})$ and $i a b(\sim 2,630 \mathrm{nt})$. These genes form an operon that also includes an intermediate region composed of 243 non-coding nucleotides. Transcription of both ITX genes is driven by a promoter located upstream of the iap gene [152]. Molecules that regulate the transcription of the ITX genes have not yet been discovered.

The iap and $i a b$ genes have been found on large, potentially conjugative, plasmids of $\sim 97 \mathrm{~kb}$ or $\sim 135 \mathrm{~kb}$. Those plasmids typically carry a silent enterotoxin (cpe) gene, the $I S 1151$ element and a $t c p$ locus (18). Interestingly, a study by Li et al. [18] suggested that a mobile genetic element, carrying iap and ibp genes, could have inserted onto a $t c p$-carrying enterotoxin plasmid in a type $\mathrm{A}$ isolate to create a progenitor ITX-plasmid. This plasmid then may spread via conjugation to other type A isolates, converting them to type E [18].

\section{Role of ITX in Animal Diseases}

Toxinotype $\mathrm{E}$ enteric infection of domestic animals was first reported in the late 1940s, and these infections have generally been considered a rare occurrence. As with type A infections and CPA, infections by $C$. perfringens type $\mathrm{E}$ are usually assumed to be mediated by ITX (Table 2), although no definitive evidence in this regard has been provided. $C$. perfringens type $\mathrm{E}$ produces enterotoxemia in rabbits. A very similar disease, thought to be mediated by a iota-like toxin, is produced in rabbits by Clostridium spiroforme. However, because of cross reactivity between $C$. perfringes type $\mathrm{E}$ and C. spiroforme toxins with the diagnostic methods currently available, it is thought that some previously reprted outbreaks of entropathies associated with C. perfringensmay have been due to $C$. spiroforme.

Both diseases are clinically characterized by diarrhea and loss of condition and characteristic necropsy changes include hemorrhages of the cecal serosa and mucosa, sometimes with involvement of the distal ileum and proximal colon, and the presence of watery mucoid content in these organs. Histologically, there is an acute necrosis of the superficial epithelium with relative sparing of the crypt epithelium, and submucosal hemorrhage and transmural hemorrhage [159].

Toxinotype $\mathrm{E}$ is an occasional cause of hemorrhagic enteritis and sudden death in beef calves [32, 160]. Type E disease has rarely been described in sheep and goats [43]. The role of ITX in these infections has not been elucidated.

\section{Clostridium Perfringens Beta 2 Toxin (CPB2)}

In recent years, a new $C$. perfringens toxin known as beta2 toxin (CPB2) has been widely reported as a potential 
contributor to $C$. perfringens related enteric diseases. The $c p b 2$ gene can be carried by all $C$. perfringens types $[18,85$, 161]

\section{Structure and Mechanism of Action}

The main properties of CPB2 are summarized in Table 3. Gibert et al. [65] first cloned the CPB2 toxin gene (cpb2) from $C$. perfringens $\mathrm{CWC} 245$, which was isolated from a piglet suffering from necrotizing enterocolitis [65]. The cloned sequence revealed an open reading frame of 265 amino acids, including a 30 amino acid signal sequence absent from the $28 \mathrm{kDa}$ mature toxin $[65,162]$. The novel CPB2 has no significant homology with beta toxin or other known bacterial toxins $[65,163,164]$. To date very few studies have been conducted to determine the biological activity of CPB2. An early report suggested that the toxin behaves similarly to CPB [165] and Gibert et al. (1997) [65] demonstrated the cytotoxic effects of CPB2 on Chinese hamster ovary and human intestinal embryonic 1407 cedll lines. This cytopathology included cell rounding, membrane blebbing and detachment from the culture matrix [65]. The toxin did modify small $G$ proteins such as actin, either by ADP-ribosylation or by UDP- glucosylation [65]. Other cell lines, such as $\mathrm{CaCo} 2$ cells have also been shown to be sensitive to the cytotoxic effects of CPB2 [161]. The cytopathic effects demonstrated by Fisher et al. [85] were similar to those described previously and the toxin induced cell death $50\left(\mathrm{TCD}_{50}\right)$ was $0.3-4 \mu \mathrm{g} / \mathrm{ml}$ for the purified native CPB2, and a recently described variant CPB2 [65]. Based on these studies, it was suggested that CPB2 toxin could act as a potential pore-forming toxin similar to other enterically-active clostridial toxins. The toxin was shown to be highly susceptible to proteolytic cleavage by trypsin [65].

The minimal lethal dose $\left(\mathrm{LD}_{50}\right)$ of $\mathrm{CPB} 2$ for mice, as described previously [65], was $0.3 \mu \mathrm{g}$ by the i.v. injection route. A mouse i.v. injection model demonstrated a weak correlation between CPB2 levels in late log-phase culture supernatants of $C$. perfringens type $\mathrm{C}$ isolates and the $\mathrm{LD}_{50}$ [85], suggesting that CPB2 could be a minor contributor to the lethality of $C$. perfringens type $\mathrm{C}$ isolates. Gibert et al. [65] showed that CPB2 toxin caused intestinal hemorrhage and necrosis in the guinea pig ligated loop model.

Detailed structure-function studies for CPB2 have not been demonstrated. However, a recombinant Clostridium perfringens CPB2 derivative has been purified using Glutathione sepharose affinity chromatography. That toxin was then crystallized using the batch-under-oil technique. Crystallographic analysis of this CPB2 crystal showed that the triangular prism shaped crystals measuring 200 microns belonged to primitive rhombohedral space group $R 3$, diffracting up to $2.9 \AA$ [166].

\section{Genetics of CPB2}

The $c p b 2$ toxin gene is transcribed during vegetative growth, especially during the exponential phase and regulation by the VirS/VirR two-component regulatory system [73]. The $c p b 2$ gene is present on $C$. perfringens type $\mathrm{D}$ isolates on plasmids $48 \mathrm{~kb}$ to $110 \mathrm{~kb}$ in size [19]. In these isolates, the gene is either present on the same plasmid carrying the etx gene or on a different plasmid. In type E isolates, $c p b 2$ gene is present on plasmids sizes varying from $70 \mathrm{~kb}$ to $90 \mathrm{~kb}$. The gene is always present on different plasmid carrying the iota toxin gene (itx) [18]. In recent studies (authors' unpublished observations), the cpb2 gene was found to be present on a $65 \mathrm{~kb}$ plasmid that also carries the etx gene, in C. perfringens type B isolates.

\section{Role of CPB2 in Animal Disease}

Over the past decade CPB2 has been associated with enteric diseases in a wide range of animals (Tables $\mathbf{3}$ and $\mathbf{4}$ ) including swine [65, 162, 167-170], cattle [28, 32, 171-174], horses [33, 35-39], sheep and goats [175, 176], and wild animals such as deer [177] and bears [178, 179]. The clinical signs observed in CPB2-mediated enteric diseases range from pasty to watery diarrhea with blood in feces, abdominal pain, and loss of body condition. It is hypothesized [165]

that CPB2 toxin may act in synergy with other major toxins of $C$. perfringens in the production of necrotic and hemorrhagic enteritis. Circumstances provoking enteric dybiosis, and other predisposing factors, could lead to diseases in these animals [165].

Based on the reported findings related to the pathology of C. perfringens encoding CPB2-related enteritis seen in food producing and wild animals [28, 32, 33, 35, 81, 169, 171, $175,177,178]$, the gross pathology is characterized by hemorrhage and necrosis of the small and large intestines. Other prominent gross pathologic lesions include swollen, hemorrhagic mesenteric lymph nodes, as well as thickened and congested abomasal walls. The characteristic histological lesions include degenerated and necrotic desquamated epithelial cells, cell debris, inflammatory cells, fibrin and variable numbers of bacterial vegetative cells and spores. The pathologic lesions observed suggest that CPB2 toxin is a primary enteric toxin affecting the nutrient absorptive capacity of the intestine, thereby debilitating the affected animal.

Despite several recent publications suggesting that CPB2 might be implicated in intestinal diseases of several animal species, most of the evidence to support this is based on isolation of $c p b 2$ - positive $C$. perfringens strains from affected animals. However, because $c p b 2$ positive strains can also be found in the intestine of many normal animals, the significance of this finding is not clear. A much larger proportion of strains carrying the $c p b 2$ gene was found in the intestine of pigs with diarrhea than in normal control animals, which strongly suggests that CPB2 is implicated in pig enteritis. However, the same does not seem to be true for other animal species and the role of CPB2 in enteric disease of those animals remains, therefore, undetermined.

\section{CLOSTRIDIUM PERFRINGENS ENTEROTOXIN (CPE)}

\section{Structure and Mechanism of Action}

The main properties of CPE are summarized in Table 3. $\mathrm{CPE}$ is a 319 amino acid protein consisting of an N-terminal domain, which is important for pore formation and cytotoxicity, and a C-terminal domain that mediates receptor binding [180]. Although CPE lacks sequence homology with other toxins, its C-terminal receptor-binding domain structurally resembles that of some Bacillus thuringiensis cry toxins [181]. 
Table 4. Epidemiological Studies Linking CPB2 and Diseases in Different Animals

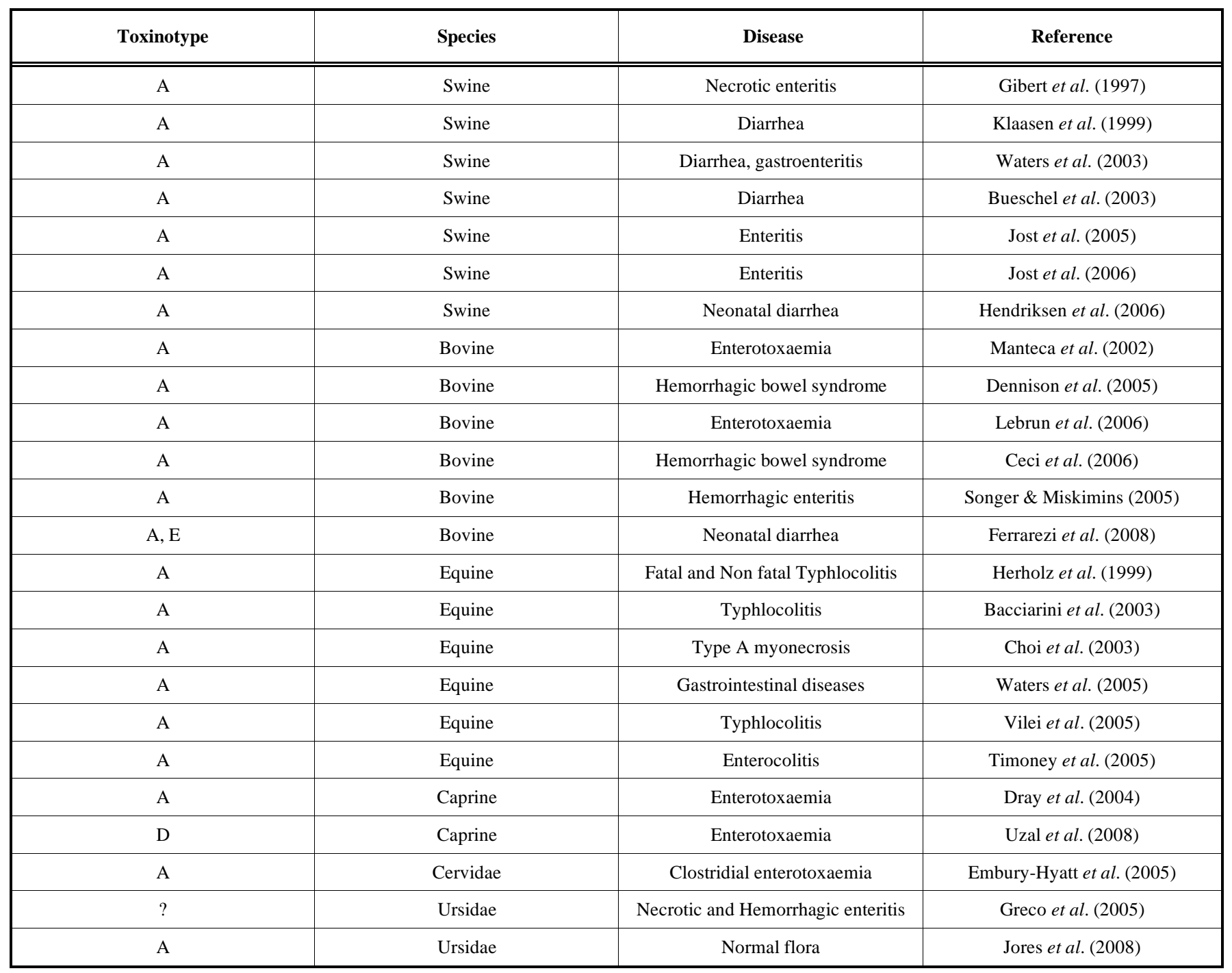

CPE action starts when the toxin binds to claudin receptors (claudins are important components of the tight junctions made by epithelial and endothelial cells), forming a small complex [182]. Several small complexes then oligomerize on the membrane surface to form a prepore named CH-1 [183]; CH-1 minimally contains six copies of $\mathrm{CPE}$, claudin receptor, and some non-receptor claudins that are likely interacting with the claudin receptors [183]. After its formation, the $\mathrm{CH}-1$ prepore inserts into the membrane bilayer to generate a cation-selective pore [182]. The resultant calcium influx activates apoptotic and oncotic cell death pathways that cause morphologic damage to the CPEtreated cells. This morphologic damage exposes the basolateral surface of the cell, allowing CPE to interact with occludin and additional claudins to form a second CPEcomplex named $\mathrm{CH}-2$ [183]. Formation of $\mathrm{CH}-2$ triggers internalization of occludin (and probably claudins), which may contribute to paracellular permeability changes and diarrhea.

All tested mammalian species are sensitive to CPE [184]. This toxin affects all small intestinal regions but is most active in the ileum $[184,185]$. CPE has only weak effects on the colon of rabbits [184] or human colonic tissue ex vivo
[48]. In the ileum, CPE causes villus shortening and epithelial desquamation [50, 184], and such damage appears necessary for accumulation of fluids and electrolytes in the lumen [186].

\section{Genetics of cpe}

The gene (cpe) encoding CPE can reside on either the chromosome or on plasmids [187, 188]. Most human foodpoisoning isolates carry cpe on the chromosome [180], and recent multi locus sequence typing (MLST) studies suggest these chromosomal cpe isolates are relatively divergent from other $C$. perfringens isolates [189]. In contrast, cpe-positive isolates recovered from diseased animals or humans suffering from nonfoodborne human gastrointestinal disease typically carry their cpe gene on large plasmids [187, 190].

In type A isolates, there are two major cpe plasmid families [189]: i) a family of $\sim 75 \mathrm{~kb}$ plasmids that also carry the beta2 toxin gene (cpb2); ii) a family of $\sim 70 \mathrm{~kb}$ plasmids lacking the $c p b 2$ gene. These two cpe plasmid families in type $\mathrm{A}$ isolates share a conserved $35 \mathrm{~kb}$ region. Some, if not all, cpe plasmids of type A isolates can transfer between $C$. perfringens via conjugation [191], probably because they possess the same tcp locus that mediates transfer of $C$. 
perfringens tetracycline resistance plasmid pCW3 [192]. Some type $\mathrm{C}$ and $\mathrm{D}$ isolates also carry a plasmid-borne cpe gene $[19,85]$, although those plasmids do not appear to be closely related to the cpe plasmids of type A isolates (unpublished). Interestingly, most type $\mathrm{E}$ isolates carry silent cpe sequences on their iota toxin-encoding plasmids, which are often related to cpe plasmids of type A isolates [18].

During human food poisoning, CPE-positive strains are ingested and then sporulate in the intestines [180, 193]. CPE is expressed during sporulation [180], in a process involving regulation by the SpoOA master regulator of sporulation [194] and alternative sigma factors [195]. The toxin then accumulates intracellularly until lysis of the sporangium, releasing CPE into the intestinal lumen.

\section{The Role of CPE in Animal Diseases}

Experiments using isogenic mutants have clearly shown that CPE production is important for $C$. perfringens type A food poisoning or nonfoodborne gastrointestinal (GI) disease isolates to cause diarrheal symptoms in experimental animals [50]. Coupled with extensive epidemiologic evidence, these findings support CPE as an important virulence factor for $C$. perfringens type $\mathrm{A}$ food poisoning or CPE-associated nonfoodborne human GI disease [180].

In contrast to the well-established role of this toxin in human GI disease, the data implicating CPE in animal disease remains more ambiguous (Table 2). Animals with diarrhea are rarely tested for the presence of CPE in their feces and diagnostic criteria for establishing CPE-mediated animals disease are lacking [81]. Nevertheless, there are case reports $[4,34,82,196-200]$ suggesting CPE may cause GI disease in both domestic animals (including dogs, pigs, horses, and goats) and possibly wild animals (such as penguins, leopards and tortoises). For example, a relatively recent study definitively showed the presence of CPEpositive, type $\mathrm{A}$ isolates and CPE in the small intestines of a goat kid suffering from necrotic enteritis [189]. Additionally, fecal CPE and CPE-positive fecal isolates have been associated with canine diarrhea [197] and it has been suggested that CPE-positive strains can cause recurrent diarrhea in dogs [199].

Finally, in horses, fecal CPE was detected in $20 \%$ of adults with diarrhea and $\sim 30 \%$ of foals with diarrhea [201]; thus supporting a role for this fecal toxin contributing to disease in those animals, while no fecal CPE was detected in healthy adult horses or foals.

\section{PERFRINGOLYSIN O OR THETA TOXIN (PFO)}

\section{Structure and Mechanism of Action}

The main properties of PFO (also called theta toxin) are summarized in Table 3. PFO is a $54 \mathrm{kDa}$ cytolytic toxin that binds to cholesterol-containing eukaryotic membranes. This toxin forms a large oligomeric prepore complex on the membrane surface prior to insertion into the cell membrane [202]. Structurally, PFO is comprised of 4 domains. The Cterminal domain (domain 4) binds cholesterol and then a conformational change in domain three exposes a $\beta$-hairpin that spontaneously inserts into the lipid bilayer [78, 202].

It has been proposed that the high affinity of PFO for cholesterol concentrates the toxin on the target membrane, promoting oligomerization and membrane insertion [203]. As mentioned, the proposed model of PFO pore formation includes the binding of water-soluble PFO monomers to cholesterol of a lipid bilayer mediated by domain 4 . However, domain 4 does not insert deeply into the membrane and is not directly involved in creating the pore. Instead, PFO monomers bound to cholesterol and orientated perpendicularly to the membrane assemble and oligomerize to form a prepore complex [78]. The oligomers consist of 40 to 50 monomers, forming on the membrane surface large arcs and rings that, after insertion of their domain three loops, lead to large pores between $300 \AA$ and $450 \AA$ in diameter [204].

\section{Genetics of PFO}

PFO is produced by all $C$. perfringens strains and the pfoA gene is located on the chromosomal DNA near the origin of replication [163, 164, 205]. PFO is synthesized with a 27 amino acid signal peptide, and the mature protein consists of 472 amino acids (53 kDa) [206].

The $p f o \mathrm{~A}$ gene is directly regulated by the VirS/VirR two-component regulatory system [22-24]. Once activated by the VirS sensor kinase, the VirR response regulator binds to specific VirR boxes (VirR box 1 and VirR box 2) located upstream of the $p f o \mathrm{~A}$ promoter, to activate its transcription [207].

The signal(s) that activates the VirS/VirR twocomponent regulatory system is unknown. The presence of enterocytes rapidly upregulates $\mathrm{PFO}$ production and transcription of the $p f o \mathrm{~A}$ gene, via the same VirS/VirR twocomponent regulatory system $[26,71]$. More recently, the $C$. perfringens Agr quorum sensing system was shown to regulate PFO toxin levels and transcription of the $p f o \mathrm{~A}$ gene in vitro $[25,26,71]$. Whether the Agr-secreted factor activates, in vitro or in the presence of eukaryotic cells, the VirS sensor kinase remains unknown.

\section{Role of PFO in Animal Diseases}

\section{Gangrene}

PFO participates with CPA in the production of local lesions of gangrene/malignant edema in humans and animals [208]. When CPA and PFO knock-out mutants of $C$. perfringens type A were used in a mouse model, elimination of both CPA and PFO toxin genes removed most of the histopathological features typical of clostridial myonecrosis. These effects were completely restored when the double mutant was complemented with the alpha-toxin structural gene. However, restoring only PFO activity produced variable results. Reconstitution of both toxins produced histopathology similar to that observed with the alphareconstituted strain (1). Studies using single PFO knock-out mutants of $C$. perfringens have shown that PFO induces tissue destruction and an anti-inflammatory response. However, the effects were less pronounced than those elicited by CPA and both toxins seem to have a synergistic action in gangrenous lesions [209].

Since PFO knock-out mutants still cause murine myonecrosis, although less severe than wild type type A strains, PFO is not considered essential for disease. Instead, PFO has the ability to affect the host inflammatory response, 
particularly the PMNL influx into the myonecrotic lesions. PFO has been implicated in the vascular accumulation of leukocytes within blood vessels and the extracellular matrix of host tissues [11, 210, 211].

PFO and CPA stimulate leucocyte adherence, probably by increasing vascular leucostasis and local ischemia. PFO is leukocytotoxic at high doses, and at a sublethal concentration it significantly stimulates the production of ICAM-1 and adherent glycoprotein CD11b/CD18 in endothelial cells, which contributes to leukostasis in vessels adjacent to gangrenous lesions $[11,210]$. The toxin effects on endothelial cells participate in disruption of endothelial integrity resulting in local edema and ultimately in systemic shock and multiorgan failure. Thus, PFO and CPA exhibit synergistic effects [52, 212].

\section{Intestinal Infections}

PFO might also have a synergistic effect with ETX. The effects of purified CPA and PFO on the lethal activity of purified ETX were studied in a mouse model. Mice were injected intravenously or intragastrically with CPA or PFO with or without ETX. Sublethal doses of CPA or PFO did not affect the lethality of ETX when either was injected together with the latter intravenously [213]. However, sublethal or lethal doses of CPA or PFO reduced survival times of mice injected simultaneously with ETX versus animals given ETX alone. When PFO was inoculated intragastrically with ETX, there was a reduction in survival time. CPA did not alter the survival time when inoculated intragastrically with ETX. These results suggest that both CPA and PFO have the potential to enhance the ETX lethal effects during enterotoxemia in natural hosts such as sheep and goats [213].

\section{CONCLUSIONS}

For many years it has been thought that most deleterious effects of $C$. perfringens infections in animals, and humans, are mediated by one or more of its powerful toxins. Toxins purified from $C$. perfringens culture supernatants have greatly improved our understanding of how these toxins mediate cellular damage. However, the specific role of individual toxins in $C$. perfringens-mediated diseases has just recently started to come to light. The recent improvement of animal models for $C$. perfringens infection and methods that inactivate toxin genes (generating toxin knock outs) have now demonstrated the specific pathologic role of several toxins of $C$. perfringens in animal and human disease. By observing a reduced or lack of virulence in knock-out strains and then full virulence with the complemented strains, the so called molecular Koch postulates have been fulfilled for several $C$. perfringens toxins, including CPB, CPA, CPE and others. These now available research tools are becoming very important in the field and are helping us: (1) to establish the role of each $C$. perfringens toxigenic type in animal or human disease; (2) to investigate the in vivo mechanism of action of their toxins; and (3) to develop more effective vaccines that will prevent lethal diseases produced by these microorganisms.

\section{ACKNOWLEDGEMENTS}

We thank Ms S. Fitisemanu for her patient typing of multiple versions of this manuscript. This work was generously supported by grant R01 AI056177-06 from National Institute of Allergy and Infectious Diseases. JEV is thankful for generous support from the Mexican National Council of Science and Technology (CONACyT).

\section{REFERENCES}

[1] Garmory HS, Chanter N, French NP, et al. Occurrence of Clostridium perfringens beta2-toxin amongst animals, determined using genotyping and subtyping PCR assays. Epidemiol Infect 2000; 124: 61-7.

[2] McClane BA, Uzal FA, Fernandez-Miyakawa M, Lyerly D, Wilkins TD. In: Dworkin SFM, Rosenburg E, Schleifer KF, Stackebrandt E, Eds. The enterotoxigenic clostridia. The Prokaryotes. New York: Springer-Verlag 2004; pp. 698-752.

[3] Sakurai J. Toxins of Clostridium perfringens. Rev Med Microbiol 1995; 6: 175-85.

[4] Songer JG. Clostridial enteric diseases of domestic animals. Clin Microbiol Rev 1996; 9: 216-34.

[5] Niilo L. Clostridium perfringens in animal disease: a review of current knowledge. Can Vet J 1980; 21: 141-8.

[6] Titball RW, Naylor CE, Basak AE. The Clostridium perfringens $\alpha-$ toxin. Anaerobe 1999; 5: 51-64.

[7] Sakurai J, Ochi S, Tanaka H. Evidence for coupling of Clostridium perfringens alpha-toxin-induced hemolysis to stimulated phosphatidic acid formation in rabbit erythrocytes. Infect Immun 1993; 61: 3711-8.

[8] Oda M, Matsuno T, Shiihara R, et al. The relationship between the metabolism of sphingomyelin species and the hemolysis of sheep erythrocytes induced by Clostridium perfringens alpha-toxin. J Lipid Res 2008; 49: 1039-47.

[9] Sakurai J, Nagahama M, Oda M. Clostridium perfringens alphatoxin: characterization and mode of action. J Biochem 2004; 136: 569-74.

[10] O'Brien DK, Melville SB. Effects of Clostridium perfringens alpha-toxin (PLC) and perfringolysin $\mathrm{O}$ (PFO) on cytotoxicity to macrophages, on escape from the phagosomes of macrophages, and on persistence of $C$. perfringens in host tissues. Infect Immun 2004; 72: 5204-15.

[11] Bryant AE, Stevens DL. Phospholipase C and perfringolysin O from Clostridium perfringens upregulate endothelial cell-leukocyte adherence molecule 1 and intercellular leukocyte adherence molecule 1 expression and induce interleukin-8 synthesis on cultured human umbilical vein endothelial cells. Infect Immun 1996; 64: 358-62.

[12] Bryant AE, Chen RY, Nagata Y, et al. Clostridial gas gangrene. II. Phospholipase C-induced activation of platelet gpIIbIIIa mediates vascular occlusion and myonecrosis in Clostridium perfringens gas gangrene. J Infect Dis 2000a; 182: 808-15.

[13] Bryant AE, Chen RY, Nagata Y, et al. Clostridial gas gangrene. I. Cellular and molecular mechanisms of microvascular dysfunction induced by exotoxins of Clostridium perfringens. J Infect Dis 2000b; 182: 799-807.

[14] Bryant AE, Bayer CR, Hayes-Schroer SM, Stevens D. Activation of platelet gpIIIa by phospholipase $\mathrm{C}$ from Clostridium perfringens involves store-operated calcium entry. J Infect Dis 2003; 187: 40817.

[15] Hickey MJ, Kwan RY, Awad MM, et al. Molecular and cellular basis of microvascular perfusion deficits induced by Clostridium perfringens and Clostridium septicum. PLoS Pathog 2008; 4: e1000045.

[16] Canard B, Cole S. Genome organization of the anaerobic pathogen Clostridium perfringens. Proc Natl Acad Sci USA 1989; 86: 667680.

[17] Cole ST, Canard B. In: Rood JI, McClane BA, Songer JG, Titball RW, Eds. Structure, organization and evolution of the genome of Clostridium perfringens. The Clostridia: molecular biology and pathogenesis. London: Academic Press 1997; pp. 49-63.

[18] Li J, Miyamoto K, McClane BA. Comparison of virulence plasmids among Clostridium perfringens type E isolates. Infect Immun 2007; 75: 1811-9.

[19] Sayeed S, Li J, McClane BA. Virulence plasmid diversity in Clostridium perfringens type D isolates. Infect Immun 2007; 75: 2391-8. 
[20] Titball RW, Hunter SEC, Martin KL, et al. Molecular cloning and nucleotide sequence of the alpha toxin (phospholipase C) of Clostridium perfringens. Infect Immun 1989; 57: 367-76.

[21] Banu S, Ohtani K, Yaguchi H, et al. Identification of novel VirR/VirS-regulated genes in Clostridium perfringens. Mol Microbiol 2000; 35: 854-64.

[22] Ba-Thein W, Lyristis M, Ohtani K, et al. The virR/virS locus regulates the transcription of genes encoding extracellular toxin production in Clostridium perfringens. J Bacteriol 1996; 178: 2514-20.

[23] Lyristis M, Bryant AE, Sloan J, et al. Identification and molecular analysis of a locus that regulates extracellular toxin production in Clostridium perfringens. Mol Microbiol 1994; 2: 761-77.

[24] Shimizu T, Ba-Thein W, Tamaki M, Hayashi H. The virR gene, a member of a class of two-component response regulators, regulates the production of perfringolysin $\mathrm{O}$, collagenase, and hemagglutinin in Clostridium perfringens. J Bacteriol 1994; 176: 1616-23.

[25] Ohtani K, Yuan Y, Hassan S, et al. Virulence gene regulation by the agr system in Clostridium perfringens. J Bacteriol 2009; 191: 3919-27.

[26] Vidal JE, Chen J, Li J, McClane BA. Use of an EZ-Tn5-based random mutagenesis system to identify a novel toxin regulatory Locus in Clostridium perfringens Strain 13. PLoS ONE 2009b; Accepted June 2009.

[27] McGowan G, Moulton JE, Rood SE. Lamb losses associated with Clostridium perfringens type A J Am Vet Med Assoc 1958; 133: 219-21.

[28] Manteca C, Daube G, Jauniaux T, et al. A role for the Clostridium perfringens beta 2 toxin in bovine enterotoxaemia? Vet Microbiol 2002; 86: 191-202.

[29] Manteca G, Daube V, Pirson B, et al. Bacterial intestinal flora associated with enterotoxaemia in Belgian Blue calves. Vet Microbiol 2001; 81: 21-32.

[30] Roeder BL, Chengappa MM, Nagataja TG, Avery TB, Kennedy GA. Experimental induction of abdominal tympany, abomasitis, and abomasal ulceration by intraruminal inoculation of Clostridium perfringens type A in nenonatal calves. Am J Vet Res 1988b; 49: 201-7.

[31] Roeder BL, Chengappa MM, Nagataja TG, Avery TB, Kennedy GA. Isolation of Clostridium perfringens type A from nenonatal calves with ruminal and abomasal tympany, abomasitis, and abomasal ulceration. JAMA 1988a; 190: 1550-5.

[32] Songer JG, Miskimins DW. Clostridial abomasitis in calves: case report and review of the literature. Anaerobe 2005; 11: 290-4.

[33] Bacciarini LN, Boerlin P, Straub R, Frey J, Grone A. Immunohistochemical localization of Clostridium perfringens beta2-toxin in the gastrointestinal tract of horses. Vet Pathol 2003; 40: 376-81.

[34] Bueschel D, Walker R, Woods L, et al. Enterotoxigenic Clostridium perfringens type A necrotic enteritis in a foal. J Am Vet Med Assoc 1998; 213: 1305-7, 280.

[35] Choi YK, Kang MS, Yoo HS, et al. Clostridium perfringens type A myonecrosis in a horse in Korea. J Vet Med Sci 2003; 65: 1245-7.

[36] Herholz C, Miserez R, Nicolet J, et al. Prevalence of beta2toxigenic Clostridium perfringens in horses with intestinal disorders. J Clin Microbiol 1999; 37: 358-61.

[37] Timoney JF, Hartmann M, Fallon L, Fallon E, Walker J. Antibody responses of mares to prepartum vaccination with Clostridium perfringens bacterin and beta2 toxin. Vet Rec 2005; 157: 810-2.

[38] Vilei EM, Schlatter Y, Perreten V, et al. Antibiotic-induced expression of a cryptic cpb2 gene in equine beta2-toxigenic Clostridium perfringens. Mol Microbiol 2005; 57: 1570-81.

[39] Waters M, Raju D, Garmory HS, Popoff MR, Sarker MR. Regulated expression of the beta2-toxin gene (cpb2) in Clostridium perfringens type a isolates from horses with gastrointestinal diseases. J Clin Microbiol 2005; 43: 4002-9.

[40] Barron NS. Enterotoxemia in goats. Vet Rec 1942; 54: 82.

[41] Baxendell SA. The diagnosis of the diseases of goats. Vade Mecum Series for Domestic Animals: Sydney, Australia University of Sydney Post-Graduate Foundation in Veterinary Science 1988; series B, no. 9 .

[42] Bhown AS, Habeeb AFSA. Structural studies on $\varepsilon$-prototoxin of Clostridium perfringens type D. Localization of the site of tryptic scission necessary for activation to $\varepsilon$-toxin. Biochem Biophys Res Commun 1977; 78: 889-96.
[43] Songer JG. Clostridial diseases of small ruminants. Vet Res 1998; 29: $219-32$

[44] Saenz MG, Venturini L, Assis RA, et al. Fibrinonecrotic enteritis of piglets in a commercial farm: a postmortem study of the prevalence and the role of lesion associated agents Isospora suis and Clostridium perfringens. Pesquisa Veterinaria Brasileira 2007; 27: 297-300.

[45] Timoney JF, Gillespie JH, Scott FW. Hagan and Bruner's microbiology and infectious diseases of domestic animals. Ithaca: Comstock Publishing Associates 1988.

[46] Niilo L, Moffatt RE, Avery RJ. Bovine enterotoxemia. II. Experimental reproduction of the disease. Can Vet J 1963; 4: 28897.

[47] Fernandez MME, Uzal FA. Morphological and physiological changes induced by Clostridium perfringens type A $\alpha$ toxin in the intestine of sheep. Am J Vet Res 2005; 66: 251-5.

[48] Fernandez MME, Pistone CV, Uzal FA, McClane BA, Ibarra C. Clostridium perfringens enterotoxin damages the human intestine in vitro. Infect Immun 2005; 73: 8407-10.

[49] Keyburn AL, Sheedy SA, Ford ME, et al. Alpha-toxin of Clostridium perfringens is not an essential virulence factor in necrotic enteritis in chickens. Infect Immun 2006; 4: 6496-500.

[50] Sarker MR, Carman RJ, McClane BA. Inactivation of the gene (cpe) encoding Clostridium perfringens enterotoxin eliminates the ability of two cpe-positive $C$. perfringens type $\mathrm{A}$ human gastrointestinal disease isolates to affect rabbit ileal loops. Mol Microbiol 1999; 33: 946-58.

[51] Sayeed S, Uzal FA, Fisher DJ, et al. Beta toxin is essential for the intestinal virulence of Clostridium perfringens type C disease isolate CN3685 in a rabbit ileal loop model. Mol Microbiol 2008; 67:15-30.

[52] Awad MM, Ellenor DM, Bod RL, Emmins JJ, Rood JI. Synergistic effects of alpha-toxin and perfringolysin $\mathrm{O}$ in Clostridium perfringens-mediated gas gangrene. Infect Immun 2001; 69: 7904 10.

[53] Flores-Diaz M, Alape-Giron A. Role of Clostridium perfringens phospholipase $\mathrm{C}$ in the pathogenesis of gas gangrene. Toxicon 2003; 42: 979-86.

[54] Stevens DL, Troyer BE, Merrick DT, Mitten JE, Olson RD. Lethal effects and cardiovascular effects of purified a- and Q-toxins from Clostridium perfringens. J Infect Dis 1988; 157: 272-9.

[55] Blood DC, Radostits OM, Henderson JA. Veterinary medicine: a textbook of the diseases of cattle, sheep, goats and horses. $6^{\text {th }}$ ed. London: Bailliere Tindall 1983.

[56] Robinson A, Manser PA. Mastitis in a heifer caused by Clostridium perfringens welchii, type A. Vet Rec 1977; 101: 37-8

[57] Hunter SE, Brown JE, Oyston PC, Sakurai J, Titball RW. Molecular genetic analysis of beta-toxin of Clostridium perfringens reveals sequence homology with alpha-toxin, gamma-toxin, and leukocidin of Staphylococcus aureus. Infect Immun 1993; 61: 3958-65.

[58] Sakurai J, Duncan CL. Some properties of beta-toxin produced by Clostridium perfringens type C. Infect Immun 1978; 21: 678-80.

[59] Shatursky O, Bayles R, Rogers M, et al. Clostridium perfringens beta-toxin forms potential-dependent, cation-selective channels in lipid bilayers. Infect Immun 2000; 68: 5546-51.

[60] Uzal FA, Saputo J, Sayeed S, et al. Development and application of new mouse models to study the pathogenesis of Clostridium perfringens type C enterotoxemias. Infect Immun 2009; 77(12): 5291-9.

[61] Bhakdi S, Tranum-Jensen J. Alpha-toxin of Staphylococcus aureus. Microbiol Rev 1991; 55: 733-51.

[62] Ferreras M, Hoper F, Dalla Serra M, et al. The interaction of Staphylococcus aureus bi-component gamma-hemolysins and leucocidins with cells and lipid membranes. Biochim Biophys Acta 1998; 1414: 108-26.

[63] Steinthorsdottir V, Fridriksdottir V, Gunnarsson E, Andresson OS Site-directed mutagenesis of Clostridium perfringens beta-toxin: expression of wild-type and mutant toxins in Bacillus subtilis. FEMS Microbiol Lett 1998; 58: 17-23.

[64] Gonzalez MR, Bischofberger M, Pernot L, van der Goot FG, Freche B. Bacterial pore-forming toxins: the (w)hole story? Cell Mol Life Sci 2008; 65: 493-507.

[65] Gibert M, Jolivet-Reynaud C, Popoff MR. Beta2 toxin, a novel toxin produced by Clostridium perfringens. Gene 1997; 203: 65-73. 
[66] Nagahama M, Hayashi S, Morimitsu S, Sakurai J. Biological activities and pore formation of Clostridium perfringens beta toxin in HL 60 cells. J Biol Chem 2003a; 278: 36934-41.

[67] Smedley JG 3rd, Fisher DJ, Sayeed S, Chakrabarti G, McClane BA. The enteric toxins of Clostridium perfringens. Rev Physiol Biochem Pharmacol 2004; 152: 183-204.

[68] Steinthorsdottir V, Halldorsson H, Andresson OS. Clostridium perfringens beta-toxin forms multimeric transmembrane pores in human endothelial cells. Microb Pathog 2000; 28: 45-50.

[69] Katayama S, Dupuy B, Daube G, China B, Cole ST. Genome mapping of Clostridium perfringens strains with I-CeuI shows many virulence genes to be plasmid-borne. Mol Gen Genet 1996; 251: 720-6.

[70] Steinthorsdottir V, Fridriksdottir V, Gunnarsson E, Andresson OS. Expression and purification of Clostridium perfringens beta-toxin glutathione S-transferase fusion protein. FEMS Microbiol Lett 1995; 130: 273-8.

[71] Vidal JE, Ohtani K, Shimizu T, McClane BA. (a) Contact with enterocyte-like Caco-2 cells induces rapid upregulation of toxin production by Clostridium perfringens type $\mathrm{C}$ isolates. Cell Microbiol 2009; 11(9): 1306-28.

[72] McGowan S, Lucet IS, Cheung JK, et al. The FxRxHrS motif: a conserved region essential for DNA binding of the VirR response regulator from Clostridium perfringens. J Mol Biol 2002; 322: 997 1011.

[73] Ohtani K, Kawsar HI, Okumura K, Hayashi H, Shimizu T. The VirR/VirS regulatory cascade affects transcription of plasmidencoded putative virulence genes in Clostridium perfringens strain 13. FEMS Microbiol Lett 2003; 222: 137-41.

[74] Okumura K, Ohtani K, Hayashi H, Shimizu T. Characterization of genes regulated directly by the VirR/VirS system in Clostridium perfringens. J Bacteriol 2008; 190: 7719-27.

[75] Hughes DT, Sperandio V. Inter-kingdom signalling: communication between bacteria and their hosts. Nat Rev Microbiol 2008; 6: 111-20.

[76] Novick RP, Geisinger E. Quorum sensing in staphylococci. Annu Rev Genet 2008; 42: 541-64.

[77] Ohtani K, Hayashi H, Shimizu T. The luxS gene is involved in cellcell signalling for toxin production in Clostridium perfringens. Mol Microbiol 2002; 44: 171-9.

[78] Shepard L, Shatursky O, Johnson A, Tweten R. The mechanism of pore assembly for a cholesterol-dependent cytolysin: formation of a large prepore complex precedes the insertion of the transmembrane b-hairpins. Biochemistry 2000; 39: 10284-93.

[79] Uzal FA. Diagnosis of Clostridium perfringens intestinal infections in sheep and goats. Anaerobe 2004; 10: 135-43.

[80] Uzal FA, Songer JG. Diagnosis of Clostridium perfringens intestinal infections in sheep and goats. J Vet Diagn Invest 2008; 20: $253-65$.

[81] Songer JG, Uzal FA. Clostridial enteric infections in pigs. J Vet Diagn Invest 2005; 17: 528-36.

[82] Fernandez Miyakawa ME, Fisher DJ, Poon R, et al. Both epsilontoxin and beta-toxin are important for the lethal properties of Clostridium perfringens type B isolates in the mouse intravenous injection model. Infect Immun 2007; 75: 1443-52.

[83] Lawrence G, Cooke R. Experimental pigbel: the production and pathology of necrotizing enteritis due to Clostridium welchii type C in the guinea-pig. Br J Exp Pathol 1980; 61: 261-71.

[84] Niilo L. Experimental production of hemorrhagic enterotoxemia by Clostridium perfringens type C in maturing lambs. Can J Vet Res 1986; 50: 32-5.

[85] Fisher DJ, Fernandez-Miyakawa ME, Sayeed S, et al. Dissecting the contributions of Clostridium perfringens type $\mathrm{C}$ toxins to lethality in the mouse intravenous injection model. Infect Immun 2006; 74: 5200-10.

[86] Nagahama M, Kihara A, Kintoh H, Oda M, Sakurai J. Involvement of tumour necrosis factor-alpha in Clostridium perfringens betatoxin-induced plasma extravasation in mice. Br J Pharmacol 2008; 153: 1296-302.

[87] Vidal JE, McClane BA, Saputo J, Parker J, Uzal FA. Effects of Clostridium perfringens beta-toxin on the rabbit small intestine and colon. Infect Immun 2008; 76: 4396-404.

[88] Sakurai J, Fujii Y, Dezaki K, Endo K. Effect of Clostridium perfringens beta toxin on blood pressure of rats. Microbiol Immunol 1984; 28: 23-31.
[89] Sakurai J, Fujii Y, Matsuura M, Endo K. Pharmacological effect of beta toxin of Clostridium perfringens type $\mathrm{C}$ on rats. Microbiol Immunol 1981; 25: 423-32.

[90] Nagahama M, Kihara A, Miyawaki T, et al. Clostridium perfringens beta-toxin is sensitive to thiol-group modification but does not require a thiol group for lethal activity. Biochim Biophys Acta 1999; 1454: 97-105.

[91] Nagahama M, Morimitsu S, Kihara A, et al. Involvement of tachykinin receptors in Clostridium perfringens beta-toxin-induced plasma extravasation. Br J Pharmacol 2003; 138: 23-30.

[92] Sakurai J, Duncan CL. Purification of beta-toxin from Clostridium perfringens type C. Infect Immun 1977; 18: 741-5.

[93] Miclard J, Jaggi M, Sutter E, et al. Clostridium perfringens betatoxin targets endothelial cells in necrotizing enteritis in piglets. Vet Microbiol 2009; 137: 320-5.

[94] Miclard J, van Baarlen J, Wyder M, Grabscheid B, Posthaus H. Clostridium perfringens beta-toxin binding to vascular endothelial cells in a human case of enteritis necroticans. J Med Microbiol 2009; 58: 826-8.

[95] Tamai E, Ishida T, Miyata S, et al. Accumulation of Clostridium perfringens epsilon-toxin in the mouse kidney and its possible biological significance. Infect Immun 2003; 71: 5371-5.

[96] Hunter SE, Clarke IN, Kelly DC, Titball RW. Cloning and nucleotide sequencing of the Clostridium perfringens epsilon-toxin gene and its expression in Escherichia coli. Infect Immun 1992; 60: 102-10.

[97] Minami J, Katayama S, Matsushita O, Matsushita C, Okabe A. Lambda-toxin of Clostridium perfringens activates the precursor of epsilon-toxin by releasing its $\mathrm{N}$ - and C-terminal peptides. Microbiol Immunol 1997; 41: 527-35

[98] Worthington RW, Mulders MS. Physical changes in the epsilon prototoxin molecule of Clostridium perfringens during enzymatic activation. Infect Immun 1977; 18: 549-51.

[99] Beal DR, Titball RW, Lindsay CD. The development of tolerance to Clostridium perfringens type D epsilon-toxin in MDCK and G402 cells. Hum Exp Toxicol 2003; 22: 593-605.

[100] Lindsay CD. Assessment of aspects of the toxicity of Clostridium perfringens epsilon toxin using the MDCK cell line. Hum Exp Toxicol 1996; 15: 904-8

[101] Buxton, D. The use of an imunoperoxidase technique to investigate by light and electron microscopy the sites of binding of Clostridium welchii type D e-toxin in mice. J Med Microbiol 1978; 11: 289-92.

[102] Uzal FA, Rolfe BE, Smith NJ, Thoma AC, Kelly WR. Resistance of ovine, caprine and bovine endothelial cells to Clostridium perfringens type D epsilon toxin in vitro. Vet Res Comm 1999; 23: 275-84.

[103] Petit L, Gibert M, Gillet D, et al. Clostridium perfringens epsilontoxin acts on MDCK cells by forming a large membrane complex. J Bacteriol 1997; 179: 6480-7.

[104] Chassin C, Bens M, de Barry J, et al. Pore-forming epsilon toxin causes membrane permeabilization and rapid ATP depletionmediated cell death in renal collecting duct cells. Am J Physiol Renal Physiol 2007; 293: F927-37.

[105] Petit L, Gibert M, Gourch A, et al. Clostridium perfringens Epsilon Toxin rapidly decreases membrane barrier permeability of polarized MDCK Cells. Cell Microbiol 2003; 5: 155-64.

[106] Finnie JW. Pathogenesis of brain damage produced in sheep by Clostridium perfringens type D epsilon toxin: a review. Aust Vet $\mathrm{J}$ 2003; 81: 219-21.

[107] Finnie JW, Blumbergs PC, Manavis J. Neuronal damage produced in rat brains by Clostridium perfringens type D epsilon-toxin. J Comp Pathol 1999; 120: 415-20.

[108] Dorca-Arevalo J, Soler-Jover A, Gibert M, et al. Binding of epsilon-toxin from Clostridium perfringens in the nervous system. Vet Microbiol 2008; 131: 14-25.

[109] Nagahama M, Sakurai J. Distribution of labeled Clostridium perfringens epsilon toxin in mice. Toxicon 1991; 29: 211-7.

[110] Soler-Jover A, Dorca J, Popoff MR, et al. Distribution of Clostridium perfringens epsilon toxin in the brains of acutely intoxicated mice and its effect upon glial cells. Toxicon 2007; 50: 530-40.

[111] Nagahama M, Sakurai J. High-affinity binding of Clostridium perfringens epsilon-toxin to rat brain. Infect Immun 1992; 60: 1237-40. 
[112] Nagahama M, Kobayashi K, Ochi S, Sakurai J. Enzyme-linked immunosorbent assay for rapid detection of toxins from Clostridium perfringens. FEMS Microbiol Lett 1991; 68: 41-4.

[113] Miyamoto O, Minami J, Toyoshima T, et al. Neurotoxicity of Clostridium perfringens epsilon-toxin for the rat hipocampus via glutamanergic system. Infect Immun 1998; 66: 2501-8.

[114] Miyamoto O, Sumitani K, Nakamura T, et al. Clostridium perfringens epsilon toxin causes excessive release of glutamate in the mouse hippocampus. FEMS Microbiol Lett 2000; 189: 109-13.

[115] Miyamoto K, Li J, Sayeed S, Akimoto S, McClane BA. Sequencing and diversity analyses reveal extensive similarities between some epsilon-toxin-encoding plasmids and the pCPF5603 Clostridium perfringens enterotoxin plasmid. J Bacteriol 2008; 190: 7178-88.

[116] Hughes ML, Poon R, Adams V, et al. Epsilon-toxin plasmids of Clostridium perfringens type D are conjugative. J Bacteriol 2007; 189: 7531-8.

[117] Rood JI. Virulence genes of Clostridium perfringens. Annu Rev Microbiol 1998; 52: 333-60.

[118] Uzal FA, Kelly WR. The effects of intravenous administration of Clostridium perfringens type D epsilon toxin on young goats and lambs. J Comp Pathol 1997; 116: 63-71.

[119] Lewis CJ. In: Martin WB, Aitken ID, Eds. Diseases of sheep. Oxford, Blackwell Science 2000; pp. 131-42.

[120] Buxton D and Morgan KT. Studies of the lesions produced in the brain of colostrum deprived lambs by Clostridium welchii (Clostridium perfringens) type D toxin. J Comp Pathol 1976; 86: 435-47.

[121] Buxton D, Linklater KA, Dyson DA. Pulpy kidney disease and its diagnosis by histological examination. Vet Rec 1978; 102: 241.

[122] Hartley WJ. A focal symmetrical encephalomalacia of lambs. N Z Vet J 1956; 4: 129-35.

[123] Barker IK, Van Dreumel AA, Palmer N. In: Jubb KF, Kennedy PC, Palmer N, Eds. Pathology of domestic animals $4^{\text {th }}$ ed. San Diego: Academic Press 1993; vol. 2: pp. 237-45.

[124] Uzal FA, Kelly WR, Morris WE, Bermudez J, Baisón M. The pathology of experimental Clostridium perfringens type D enterotoxemia in sheep. J Vet Diagn Invest 2004; 16: 403-11.

[125] Bullen JJ, Batty II. Enterotoxemia of sheep. Vet Rec 1957; 69: 1268-76.

[126] Blackwell TE, Butler DG, Bell JA. Enterotoxemia in the goat: the humoral response and local tissue reaction following vaccination with two different bacterin-toxoids. Can J Comp Pathol 1992; 47: 127-32.

[127] Blackwell TE, Butler DG, Prescott JF, Wilcock BP. Differences in signs and lesions in sheep and goats with enterotoxemia induced by intraduodenal infusion of Clostridium perfringens type D. Am J Vet Res 1991; 52: 1147-152.

[128] Smith MC, Sherman DM. Goat medicine. Philadelphia: Lea and Febiger 1994.

[129] Shanks PL. Enterotoxemia in goats. Vet Rec 1949; 61: 262-4.

[130] Uzal FA, Glastonbury JR, Kelly WR, Thomas R. Caprine enterotoxemia associated with cerebral microangiopathy. Vet Rec 1997; 141: 224-6.

[131] Griesemer RA, Krill WR. Enterotoxemia in beef calves-30 years observation. J Am Vet Med Assoc 1962; 140: 154-8.

[132] Griner LA, Aichelman WW, Brown GD. Clostridium perfringens type D (ETX) enterotoxemia in brown swiss dairy calves. J Am Vet Med Assoc 1956; 129: 375-6.

[133] Keast JC, McBarron EJ. A case of bovine enterotoxemia. Aust Vet J 1954; 56: 305-6.

[134] Brown CC, Baker DC, Barker IK. In: Maxie MG, Ed. Jubb, Kennedy and Palmer's Pathology of domestic animals, 5th ed. Philadelphia: Elsevier 2007; vol. 2: pp. 1-296.

[135] Barber DML. Focal symmetrical encephalomalacia in young cattle. Vet Rec 1981; 109: 87-8.

[136] Buxton D. Focal encephalomalacia in young cattle. Vet Rec 1981; 108: 459.

[137] Fairley RA. Lesions in the brains of three cattle resembling the lesions of enterotoxemia in lambs. NZ Vet J 2005; 53: 356-8.

[138] Munday BL, Mason RW, Cumming R. Observations of diseases of the central system of cattle in Tasmania. Aust Vet J 1973; 49: 4515 .

[139] Munday BL, Mason RW, Hartley WJ. Encephalopathies in cattle in Tasmania. Aust Vet J 1976; 52: 93-6.
[140] Watson PJ, Scholes SF. Clostridium perfringens type D epsilon intoxication in one-day-old calves. Vet Rec 2009; 164; 816-8.

[141] Uzal FA, Kelly WR, Morris WE, Assis RA. Effects of intravenous injection of Clostridium perfringens type D epsilon toxin in calves. J Comp Pathol 2002; 126: 71-5.

[142] Finnie JW. Histopathological changes in the brain of mice given Clostridium perfringens type D epsilon toxin. J Comp Pathol 1984a; 94: 363-70.

[143] Finnie JW. Ultrastructural changes in the brain of mice given Clostridium perfringens type D epsilon toxin. J Comp Pathol 1984b; 94: 445-52.

[144] Finnie JW, Manavis J, Blumbergs PC. Aquaporin-4 in acute cerebral edema produced by Clostridium perfringens type D epsilon toxin. Vet Pathol 2008; 45: 307-9.

[145] Buxton D. In vitro effects of Clostridium welchii type-D epsilon toxin on guinea pig, mouse, rabbit and sheep cells. J Med Microbiol 1978; 11: 299-302

[146] Buxton D. Use of horseradish peroxidase to study the antagonism of Clostridium welchii (Cl. perfringens) type D epsilon toxin in mice by the formalinized epsilon prototoxin. J Comp Pathol 1976; 86: 67-72.

[147] Zhu C, Ghabriel MN, Blumbergs PC, et al. Clostridium perfringens prototoxin-induced alteration of endothelial barrier antigen (EBA) immunoreactivity at the blood brain barrier (BBB). Exp Neurol 2001; 169: 72-82.

[148] Facury Filho EJ, Carvalho AU, Assis RA, et al. Clinicopathological features of experimental Clostridium perfringens type D enterotoxemia in cattle. Vet Pathol 2009; [Epub ahead of print]

[149] Barth H, Blöcker D, Behlke J, et al. Cellular uptake of Clostridium botulinum $\mathrm{C} 2$ toxin requires oligomerization and acidification. $\mathrm{J}$ Biol Chem 2000; 275: 18704-11.

[150] Tsuge H, Nagahama M, Oda M, et al. Structural basis of actin recognition and arginine ADP-ribosylation by Clostridium perfringens iota-toxin. Proc Natl Acad Sci USA 2008; 105: 7399404.

[151] Gibert M, Petit L, Raffestin S, Okabe A, Popoff MR. Clostridium perfringens iota-toxin requires activation of both binding and enzymatic components for cytopathic activity. Infect Immun 2000 68: 3848-53.

[152] Perelle S, Gibert M, Boquet P, Popoff MR. Characterization of Clostridium perfringens iota toxin genes and expression in Escherichia coli. Infect Immun 1993; 61: 5147-56.

[153] Simpson LL, Stiles BG, Zepeda HH, Wilkins TD. Molecular basis for the pathological actions of Clostridium perfringens iota toxin. Infect Immun 1987; 55: 118-22.

[154] Stiles B, Hale ML, Marvaud JC, Popoff MR. Clostridium perfringens iota toxin: binding studies and characterization of cel surface receptor by fluorescence-activated cytometry. Infect Immune 2000; 68: 3475-84.

[155] Bachmeyer C, Benz R, Barth H, et al. Interaction of Clostridium botulinum $\mathrm{C} 2$ toxin with lipid lilayer membranes and Vero cells: inhabitation of channel function in chloroquine and related compounds in vitro and toxin action in vivo. FASEB J 2001; 15 : 1658-60.

[156] Schmid A, Benz R, Just I, Aktories K. Interaction of Clostridium botulinum $\mathrm{C} 2$ toxin with lipid bilayer membranes. J Biol Chem 1994; 269: 16706-11.

[157] Richard JF, Mainguy G, Gibert M, et al. Transcytosis of iota toxin across polarized CaCo-2 cell monolayers. Mol Microbiol 2002; 43 . 907-17.

[158] Verschueren H, van der Taelen I, Dewit J, et al. Effects of Clostridium botulinum $\mathrm{C} 2$ toxin and cytochalasin $\mathrm{D}$ on in vitro invasiveness, motility and F-actin content of a murine T-lymphoma cell line. Eur J Cell Biol 1995; 66: 335-41.

[159] Percy DH, Barthold SW. Pathology of laboratory rodents and rabbits. Victoria, Australia: Blackwell Publishing 2007.

[160] Hart B, Hopper PT. Enterotoxemia of calves due to Clostridium welchii type E. Aust Vet J 1967; 43: 360-3.

[161] Fisher DJ, Miyamoto K, Harrison B, et al. Association of beta2 toxin production with Clostridium perfringens type A human gastrointestinal disease isolates carrying a plasmid enterotoxin gene. Mol Microbiol 2005; 56: 747-62.

[162] Bueschel DM, Jost BH, Billington SJ, Trinh HT, Songer JG. Prevalence of $\mathrm{cpb} 2$, encoding beta2 toxin, in Clostridium perfringens field isolates: correlation of genotype with phenotype. Vet Microbiol 2003; 94: 121-9. 
[163] Shimizu T, Ohtani K, Hirakawa H, et al. Complete genome sequence of Clostridium perfringens, an anaerobic flesh-eater. Proc Natl Acad Sci 2002b; 99: 996-1001.

[164] Shimizu T, Yaguchi H, Ohtani K, Banu S, Hayashi H. Clostridial VirR/VirS regulon involves a regulatory RNA molecule for expression of toxins. Mol Microbiol 2002a; 43: 257-65.

[165] Schotte U, Truyen U, Neubauer H. Significance of beta 2-toxigenic Clostridium perfringens infections in animals and their predisposing factors--a review. J Vet Med B Infect Dis Vet Public Health 2004; 51: 423-6.

[166] Gurjar AA, Yennawar NH, Yennawar HP, et al. Expression, crystallization and preliminary X-ray diffraction studies of recombinant Clostridium perfringens beta 2-toxin. Acta Crystallogr Sect F Struct Biol Cryst Commun 2007; 63: 484-7.

[167] Hendriksen SW, van Leengoed LA, Roest HI, van Nes A. Neonatal diarrhoea in pigs: alpha- and beta2-toxin produced by Clostridium perfringens. Tijdschr Diergeneeskd 2006; 131: 910-3.

[168] Jost BH, Billington SJ, Trinh HT, Bueschel DM, Songer JG. Atypical cpb2 genes, encoding beta2-toxin in Clostridium perfringens isolates of nonporcine origin. Infect Immun 2005; 73: 652-6.

[169] Klaasen HL, Molkenboer MJ, Bakker J, et al. Detection of the beta2 toxin gene of Clostridium perfringens in diarrhoeic piglets in The Netherlands and Switzerland. FEMS Immunol Med Microbiol 1999; 24: 325-32.

[170] Waters M, Savoie A, Garmory HS, et al. Genotyping and phenotyping of beta2-toxigenic Clostridium perfringens fecal isolates associated with gastrointestinal diseases in piglets. $\mathrm{J}$ Clin Microbiol 2003; 41: 3584-91.

[171] Ceci L, Paradies P, Sasanelli M, et al. Haemorrhagic bowel syndrome in dairy cattle: possible role of Clostridium perfringens type A in the disease complex. J Vet Med A Physiol Pathol Clin Med 2006; 53: 518-23.

[172] Dennison AC, Van Metre DC, Morley PS, et al. Comparison of the odds of isolation, genotypes, and in vivo production of major toxins by Clostridium perfringens obtained from the gastrointestinal tract of dairy cows with hemorrhagic bowel syndrome or left-displaced abomasum. J Am Vet Med Assoc 2005; 227: 132-8.

[173] Ferrarezi MC, Cardoso TC, Dutra IS. Genotyping of Clostridium perfringens isolated from calves with neonatal diarrhea. Anaerobe 2008; 4: 328-31.

[174] Lebrun M, Filee P, Mousset B, et al. The expression of Clostridium perfringens consensus beta2 toxin is associated with bovine enterotoxaemia syndrome. Vet Microbiol 2007; 120: 151-7.

[175] Dray T. Clostridium perfringens type A and beta2 toxin associated with enterotoxemia in a 5-week-old goat. Can Vet J 2004; 45: 251 3.

[176] Uzal FA, Fisher DJ, Saputo J, et al. Ulcerative enterocolitis in two goats associated with enterotoxin- and beta2 toxin-positive Clostridium perfringens type D. J Vet Diagn Invest 2008; 20: 66872.

[177] Embury-Hyatt CK, Wobeser G, Simko E, Woodbury MR. Investigation of a syndrome of sudden death, splenomegaly, and small intestinal hemorrhage in farmed deer. Can Vet $\mathrm{J} 2005 ; 46$ : 702-8.

[178] Greco G, Madio A, Martella V, et al. Enterotoxemia associated with beta2 toxin-producing Clostridium perfringens type A in two Asiatic black bears (Selenarctos thibetanus). J Vet Diagn Invest 2005; 17: 186-9.

[179] Jores J, Derocher AE, Staubach C, Aschfalk A. Occurrence and prevalence of Clostridium perfringens in polar bears from Svalbard, Norway. J Wild Dis 2008; 44: 155-8.

[180] McClane BA, Lyerly DL, Wilkins TD. In: Fischetti RPN - VA, Feretti JJ, Portnoy DA, Rood JI, Eds. Enterotoxic clostridia: Clostridium perfringens type A and Clostridium difficile. Gram positive pathogens. Washington DC: ASM Press 2006; PP. 703-14.

[181] Van Itallie CM, Betts L, Smedley JG 3rd, McClane BA, Anderson JM. Structure of the claudin-binding domain of Clostridium perfringens enterotoxin. J Biol Chem 2008; 283: 268-74.

[182] Sayeed S, Robertson SL, Caserta JA, McClane BA. In: Bruggemann H, Gottschalk G, Eds. Improved understanding of the action and genetics of Clostridium perfringens enterotoxin suggests potential application for cancer therapy and drug delivery. Clostridia: Molecular Biology in the post-genomic era. Norfolk: Caister academic press 2009; pp. 29-46.
[183] Robertson SL, Smedley JG, Singh U, et al. Compositional and stoichiometric analysis of Clostridium perfringens enterotoxin complexes in Caco- 2 cells and claudin 4 fibroblast transfectants. Cell Microbiol 2007; 9: 2734-55.

[184] McDonel JL. The molecular mode of action of Clostridium perfringens enterotoxin. Am J Clin Nutr 1979; 32: 210-8.

[185] McDonel JL, Duncan CL. Regional localization of activity of Clostridium perfringens type A enterotoxin in the rabbit ileum, jejunum, and duodenum. J Infect Dis 1977; 136: 661-6.

[186] Smedley JG 3rd, Saputo J, Parker JC, et al. Noncytotoxic Clostridium perfringens enterotoxin (CPE) variants localize $\mathrm{CPE}$ intestinal binding and demonstrate a relationship between $\mathrm{CPE}$ induced cytotoxicity and enterotoxicity. Infect Immun 2008; 76 : 3793-800.

[187] Collie RE, McClane BA. Evidence that the enterotoxin gene can be episomal in Clostridium perfringens isolates associated with nonfood-borne human gastrointestinal diseases. J Clin Microbiol 1998; 36: 30-6.

[188] Cornillot E, Saint-Joanis B, Daube G, et al. The enterotoxin gene (cpe) of Clostridium perfringens can be chromosomal or plasmidborne. Mol Microbiol 1995; 15: 639-47.

[189] Deguchi A, Miyamoto K, Kuwahara T, et al. Genetic characterization of type A enterotoxigenic Clostridium perfringens strains. PLoS One 2009; 4: e5598.

[190] Sparks SG, Carman RJ, Sarker MR, McClane BA. Genotyping of enterotoxigenic Clostridium perfringens fecal isolates associated with antibiotic-associated diarrhea and food poisoning in North America. J Clin Microbiol 2001; 39: 883-8.

[191] Brynestad S, Sarker MR, McClane BA, Granum PE, Rood JI. Enterotoxin plasmid from Clostridium perfringens is conjugative. Infect Immun 2001; 69: 3483-7.

[192] Bannam TL, Teng WL, Bulach D, Lyras D, Rood JI. Functional identification of conjugation and replication regions of the tetracycline resistance plasmid pCW3 from Clostridium perfringens. J Bacteriol 2006; 188: 4942-51.

[193] Johnson S, Gerding DN. In: Rood JI, McClane BA, Songer JG, Titball RW, Eds. The clostridia. molecular biology and pathogenesis. London: Academic Press 1997; pp. 117-40.

[194] Huang IH, Waters M, Grau RR, Sarker MR. Disruption of the gene (spo0A) encoding sporulation transcription factor blocks endospore formation and enterotoxin production in enterotoxigenic Clostridium perfringens type A. FEMS Microbiol Lett 2004; 233: 233.

[195] Harry KH, Zhou R, Kroos L, Melville SB. Sporulation and enterotoxin (CPE) synthesis are controlled by the sporulationspecific sigma factors SigE and SigK in Clostridium perfringens. J Bacteriol 2009; 191: 2728-42.

[196] Greenwood AG. Identification of Clostridium perfringens enterotoxin in penguins. Vet Rec 2000; 146:172.

[197] Marks SL, Kather EJ, Kass PH, Melli AC. Genotypic and phenotypic characterization of Clostridium perfringens and Clostridium difficile in diarrheic and healthy dogs. J Vet Intern Med 2002; 16: 533-40.

[198] Neiffer DL. Clostridium perfringens enterotoxicosis in two Amur leopards (Panthera pardus orientalis). J Zoo Wild Med 2001; 32: 134-5.

[199] Weese JS, Greenwood SJ, Staempfli HR. Recurrent diarrhea associated with enterotoxigenic Clostridium perfringens in 2 dogs. Can Vet J 2001; 42: 292-4.

[200] Weese JS, Staempfli HR. Diarrhea associated with enterotoxigenic Clostridium perfringens in a red-footed tortoise (Geochelone carbonaria). J Zoo Wild Med 2000; 31: 265-6.

[201] Weese JS, Staempfli HR, Prescott JF. A prospective study of the roles of clostridium difficile and enterotoxigenic Clostridium perfringens in equine diarrhoea. Equine Vet J 2001b; 33: 403-9.

[202] Shepard LA, Heuck AP, Hamman BD, et al. Identification of a membrane-spanning domain of the thiol-activated pore-forming toxin Clostridium perfringens perfringolysin O: an alpha-helical to beta-sheet transition identified by fluorescence spectroscopy. Biochemistry 1998; 37: 14563-74.

[203] Rossjohn J, Feil SC, McKinstry WJ, Tweten RK, Parker MW. Structure of a cholesterol-binding thiol-activated cytolysin and a model of its membrane form. Cell 1997; 89: 685-92.

[204] Dang TX, Hotze EM, Rouiller I, Tweten RK, Wilson-Kubalek EM. Prepore to pore transition of a cholesterol-dependent cytolysin visualized by electron microscopy. J Struct Biol 2005; 150: 100-8. 
[205] Katayama S, Dupuy B, Cole ST. Rapid expansion of the physical and genetic map of the chromosome of Clostridium perfringens CPN50. J Bacteriol 1995; 177: 5680-5.

[206] Tweten RK. Nucleotide sequence of the gene for perfringolysin $O$ (theta toxin) from Clostridium perfringens: significant homology with the genes for streptolysin and pneumolysin. Infect Immun 1988; 56; 3235-40.

[207] Cheung JK, Dupuy B, Deveson DS, Rood JI. The spatial organization of the VirR boxes is critical for VirR-mediated expression of the perfringolysin $\mathrm{O}$ gene, pfoA, from Clostridium perfringens. J Bacteriol 2004; 186: 3321-30.

[208] Kennedy CL, Smith DJ, Lyras D, Chakravorty A, Rood JI. Programmed cellular necrosis mediated by the pore-forming alphatoxin from Clostridium septicum. PLoS Pathog 2009 5: e1000516.

[209] Stevens DL, Tweten RK, Awad MM, Rood JI, Bryant AE. Clostridial gas gangrene: evidence that a and $t$ toxin differentially modulate the immune response and induce acute tissue necrosis. J Infect Dis 1997; 176: 189-95.
[210] Bryant AE, Bergstrom R, Zimmerman GA, et al. Clostridium perfringens invasiveness is enhanced by effects of theta toxin upon PMNL structure and function: The roles of leukocytotoxicity and expression of CD11/CD18 adherence glycoprotein. FEMS Immunol Med Microbiol 1993; 7: 321-6.

[211] Ellemor D, Baird R, Awad M, Boyd R, Emmins J. Use of genetically manipulated strains of Clostridium perfringens reveals that both alpha toxin and tetha toxin are required for vascular leukostasis to occur in experimental gas gangrene. Infect Immun 1999; 67: 4902-7.

[212] Stevens DL, Bryant AE. The role of Clostridial toxins in the pathogenesis of gas gangrene. Clin Infect Dis 2002; 35: S93-S100.

[213] Fernandez-Miyakawa ME, Jost BH, Billington SJ, Uzal FA. Lethal effects of Clostridium perfringens epsilon toxin are potentiated by alpha and perfringolysin-O toxins in a mouse model. Vet Microbiol 2008; 127: 379-85.

Received: August 24, 2009

Revised: September 09, 2009

Accepted: September 11, 2009

(C) Uzal et al.; Licensee Bentham Open.

This is an open access article licensed under the terms of the Creative Commons Attribution Non-Commercial License (http: //creativecommons.org/licenses/by$\mathrm{nc} / 3.0 /$ ) which permits unrestricted, non-commercial use, distribution and reproduction in any medium, provided the work is properly cited. 